Historic, Archive Document

Do not assume content reflects current scientific knowledge, policies, or practices. 



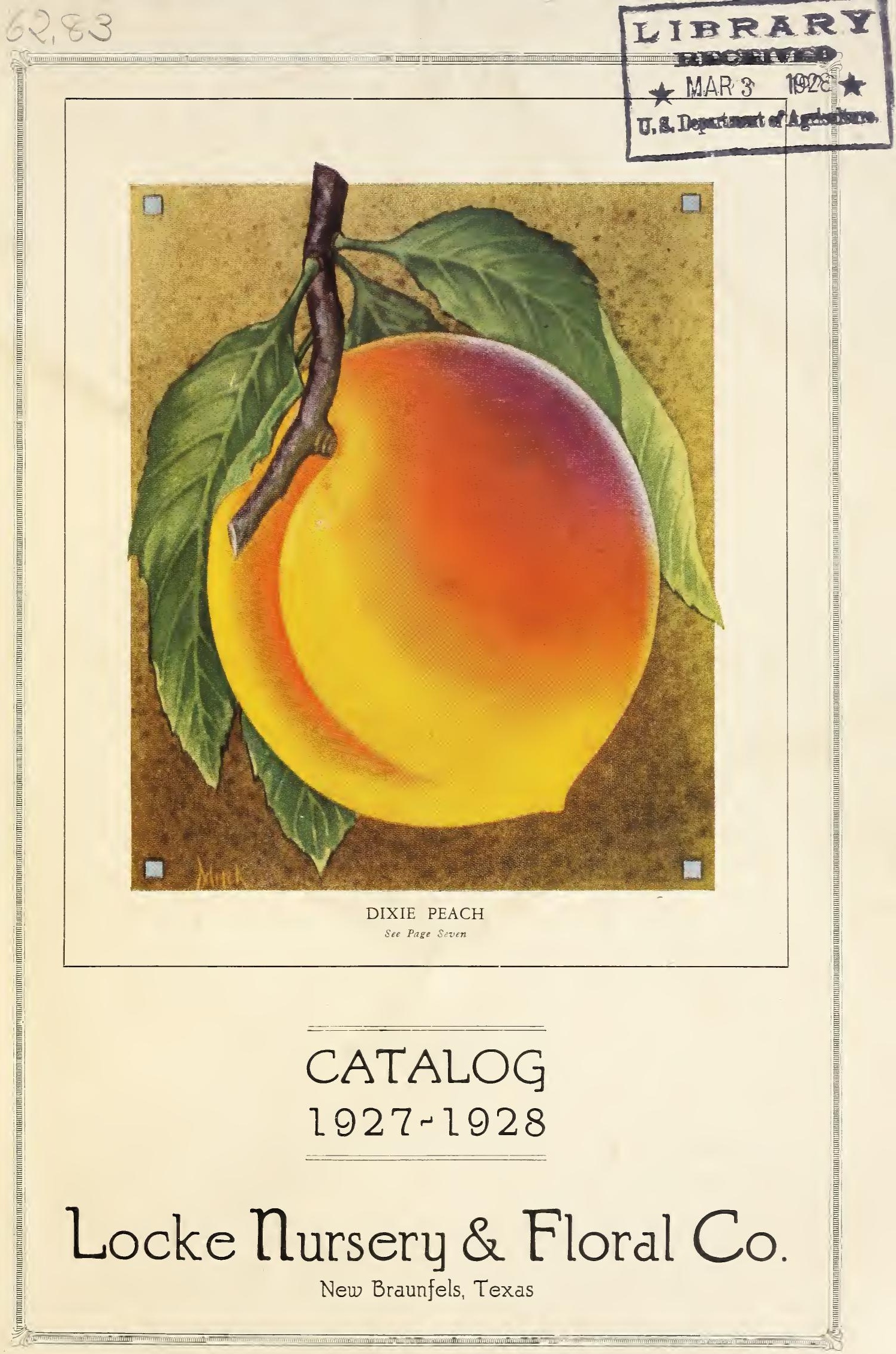




\section{Our THOUSANDS of Friends and Customers in the South}

Varieties of trees and seeds that have mostly originated here on our grounds, which are the result of my own work in horticulture all these years, are well known to many of my friends and customers. Their own success with these varieties have been the strongest possible recommendations for them.

For, of course, the varieties, having originated here, are the best for this section.

Way back in 1886 we started here in the nursery business. We have been at it ever since. We began on a little 5 -acre patch, but soon outgrew this place. Now we have over 100 acres in Nursery Stock.

We have planted more roses and fruit trees this year than ever before. These have made good growth, too, and are fully up to our usual well known standard. Our stocks of evergreens, ornamentals and flowering shrubs are the largest and finest in the South. So we feel we can please you. We have no agents. This is our sole representative. We do but very little advertising. We depend on the high quality of our goods to hold our customers and bring us new ones. Our prices are reasonablevery low, in fact, quality considered-so low we have to sell for cash only.

\section{SHIPPING INSTRUCTIONS}

Customers will please state whether they wish their order to be sent by Parcel Post, Express or Freight. The size limit of Parcel Post is 84 inches in combined girth and length. For this reason no tree over 4 feet high can be sent by Parcel Post and must be sent by Express.

Express is the most satisfactory for shipping trees from 10 pounds to 300 pounds, and not more costly than freight, and much quicker.

We guarantee all trees to be healthy, free from disease, and true to name.

We pay no transportation charges.

We do not employ any agents or salesmen, and have no connection with any other nursery. We deal direct with all our customers and are directly responsible to them and no one else.

We ship our orders just as soon as possible after receiving same and do most work ourselves and take great pride in packing in the best manner possible in order that our customers get their trees in good condition.

Yours for mole and better Texas fruits,

LOCKE NURSERY AND FLORAL COMPANY,

New Braunfels, Comal County, Texas. 


\section{Brief, But Very Important Planting Instructions}

Which are More or Less Amplified Throughout This Catalog

We send out planting instructions with each order. Some cultural hints are given under each heading throughout the catalog. Briefly this is what you should do:

On Arrival of Trees, place in a protected place, keeping moist if held for a day only, else bury roots in ground at once.

Pruning is Necessary. General rule is to cut off one-half to two-thirds the length of the lateral branches. This balances loss of root system necessary in digging the tree Remove all label wires. Plant Carefully. Dig ample holes to take roots without crowding. Plant not more than an inch or two deeper than they formeriy stood. Work fine soil into the roots, be sure there are no air pockets and tamp earth solid to insure contact with every root. Water, if possible, before applying the top three inches

Mulching or Cultivation is necessary if good growth is expected. Both conserve the moisture, which is very essential.

Watering. Sprinkling and spraying are of little value during times of drought. Remember the roots of most plants are buried 8 to 10 inches in the soil and it takes a good soaking to reach them. Let the hose run slowly for an hour or so, or several hours.

\section{PLANTING INFORMATION}

Many do not realize the importance of giving trees a little care upon arrival. For this reason we are giving this space in our catalog for your benefit Failure to get satisfactory results can be largely avoided by observing the few simple but important instructions here given.

\section{CARE UPON ARRIVAL}

On arrival of the trees from the Nursery, if un. able to plant immediately, and if the trees are dug without a ball of earth intact (Balled), they should be taken from the bale or box at once, counted and the individual tree examined. Should there be a Bare-rooted stok shis Bare-rooted stock should be immediately heeled in a well-drained, moist piece of sandy ground in order that the soil may thoroughly pulverize between the roots, keeping them from air-drying. The soil should be thoroughly packed around the are planted.

\section{STOCK ARRIVING IN FREEZING WEATHER}

If frozen when received, do not open the bales or boxes, but place them in a cellar or some cool, dark room that is free from frost, and let them remain until all frost is drawn out. If no cellar or frost proof room, bury the box or bales in sawdust or dirt until thawed. The point is to get the frost entirely out without sudden exposure of stock to heat, light or air. Even if frozen solid, the stock will not be injured if handled in this manner.

Time of Planting. In this climate vegetation, although inactive in winter for the formation of leaves and new wood, is never so as to new roots. A tree transplanted in the early winter will, by the ensuing spring, have grown sufficient new roots to give it a firm hold in the ground, and will grow off rapidly when active vegetation commences. Plant as early after the first killing frost as practicable, although hardy stock can be safely transplanted any time during the winter when the ground is not too wet or frozen. Planting can be ground is not too wet or frozen. Planting can be
continued until the middle of March, or until just before the buds begin to swell.

Preparation of the Soil. The most desirable soil for fruit trees is a rich loam, naturally dry or made so by drainage. Peaches and plums must be planted on high, well-drained soil. Before planting, prepare the land by thoroughly plowing and subsoiling, first using soiling, first using a two-horse plow, followed by a tances, and dig holes at least two feet wide and two feet deep; fill the holes by breaking in the sides, commencing at the bottom and going upward. Use surface soil in filling up, and with this mix one or two shovel-fuls of thoroughly decomposed barnyard manure, or use one or two pounds of good bone meal. All fertilizers must be thoroughly incorporated with the soil. Avoid the contact of the roots with heating manures.

We strongly advocate digging holes with dynamite whenever feasible.

\section{PREPARATION OF TREES AND HOW TO
PLANT}

Before planting, remove the broken roots; cut back one-year peach, apple, pear, cherry and plum trees to a naked stem $1 \frac{1 / 2}{2}$ to $2 \frac{1}{2}$ feet high, leaving no side branches. Two-year old trees should have their branches cut less; the lower limbs less than those above, cutting in shorter as you go upward, leaving the leader the longest. The trees should be set about 2 inches deeper than they stood in the nursery.

Cultivation. You cannot expect to get good results from your trees unless you keep them well cultivated. The soil must be frequently stirred during the summer. The area immediately around the trees must be kept free from grass and weeds, and this portion of the orchard should receive and this portion of the orchard shanches which especial attention. All suckers or branches which
start below the head of the tree should be removed.

\section{FERTILIZING}

Do not use unrotted stable manure or compost fertilizer when trees are planted. A few pounds of bone meal or a few shovels full of well rotted stable manure can be used at the bottom of the hole with good results at the time trees are planted. When filling the hole use soil which came from the bottom of the hole at the surface. Best rom the bottom of the hole at the surface. Best results with unrotted manure are attained by using it as a mulch, after the trees are planted. Comto bud out. It is applied by digging a trench around the tree or plant, a few inches past the end of the newly PLANTED ROOTS: Then fill trench to cover fertilizer. For the first two years cultivate the orchard during summer in some crop cultivate the orchard do the location, such as cotton, vegetables, suited to the location, such as cotton, vegetables, melons, peas, peanuts, velvet or soy beans, giving
the preference to leguminous crops. Never plant corn or small grain in your orchard.

It is always advisable to sow in the fall a cover crop, such as clover, vetch or rye, using a suitable fertilizer. Turn under this cover crop in the early spring. When soils are deficient in lime and potash, supply this deficiency with an application potash, supply this deficiency with an application of lime, bone meal, hardwood ashes or high grade factory results can be expected only when the orchard is supplied with the proper plant food and receives careful cultivation.

\section{SELECTION OF TREES}

For this climate experience has taught us that one and two year old trees of thrifty growth (except peaches, only one-year trees of which should be planted), are the most desirable. Purchasers should bear in mind that such trees can be removed from the nursery with all their roots, whereas a four or five-year old tree cannot be taken up without cutting away a large portion of them. Success in transplanting is increased according as attention is paid in selecting well-rooted trees, instead of heavily-branched ones. Give as many sound roots and as little head to a tree as possible.

\section{PROTECTING THE TREES}

If trees are planted near walks or drives or where cattle are likely to rub thom, place sost, lished.

\section{FUTURE CARE}

While plants may live and thrive satisfactorly without proper attention, it is imperative for best results that planting care be followed by continued rtention. combatted. Further information concerning care of plants is found in the Farmer's Series of Bulletins issued by the United States Department of Agriculture and the Extension Service Departments of our State Agricultural Colleges. We suggest that all interested planters write for lists of these bulletins.

\section{STATE AGRICULTURAL COLLEGES}

from which the latest spraying and similar information may be obtained through correspondence:

Arkansas-Fayetteville.

Colorado-Fort Collins.

Illinois-Urbana.

Indiana-Lafayette.

Iowa-Ames.

Kansas State College-Manhattan.

Kansas University-Lawrence.

Kentucky-Lexington.

Michigan-East Lansing.

Missouri-Columbia.

Nebraska-Lincoln.

New Mexico-Agricultural College.

Oklahoma-Stillwater.

South Dakota-Brookings.

Texas-College Station. 


\section{Our Policies, Service and Business Information}

(The paragraphs are numbered for easy reference in case of correspondence)

1. The ORDER BLANK accompanying this catalog is for the convenience of customers, and its use will facilitate the filling of orders. Any other matter should be written on a separate sheet of paper.

2. ALWAYS GIVE FULL ADDRESS every time you write. This is important. Please write your name and address very plainly, so that nothing will have to be deciphered or guessed.

3. TERMS. Our terms are Cash with Order. The prices are Net Cash. All prices have been so figured and discounts deducted. If we extended any credit or opened accounts, it would be necessary to have higher or increased prices.

4. REMITTANCES should be made payable to Locke Floral and Nursery Company and the best way to send them is by Bank Draft, Express Money Order, Postoffice Money Order. Money, if sent by registered mail, is all right. Checks will be accepted from responsible parties.

5. RESERVATIONS of stock will be made when one-half of the price accompanies the order. This is to accommodate those who are not ready to plant early in the season but wish to secure the stock before same is sold.

6. SHIPPING INSTRUCTIONS. Customers will please state whether they wish their orders to be sent by Parcel Post, Express or Freight.

\section{OUR SUGGESTIONS}

6a. PARCEL POST. The size limit for Parcel Post is 84 inches in combined girth and length. For this reason no tree over four feet high can be sent, unless cut back, even if it weighs only a pound or two.

6b. PARCEL POST CHARGES HAVE TO BE PREPAID, and for this reason money will have to be sent to cover cost of postal charges

7. EXPRESS. For all shipments up to 300 pounds the Express is the most satisfactory, and not any more costly than freight. Even in heavy shipments Express may cost more but the quicker service pays.

7a. FREIGHT. For very large and heavy shipments, and where quick delivery is not an element. All our shipments are so packed that they will carry several weeks by freight without injury to stock.

7b. EXPRESS AND FREIGHT SHIPMENTS can be sent "Charges Collect," and such charges are no more than if "Prepaid." For this reason no money has to be sent to cover Express or Freight charges.

8. ERRORS AND COMPLAINTS. We want every order to be satisfactorily filled, and the dea is not complete until satisfaction is given. So if there is any error or dissatisfaction we will appreciate it very much if you will let us know as soon after receipt of stock as possible or not later than five days to admit of adjustment. We immediately and cheerfully correct anv errors of our own.

9. IT IS TO OUR INTEREST to send out the very best stock possible, true to label, healthy and packed to arrive in good condition, and this we will do. But as we cannot prevent drouths, freezes, ravishes of insects, rabbits, diseases, planting in unsuitable soils, or locations, careless or improper planting, indifferent or ignorant cultivaimproper planting, indifferent or ignorant cultivathat arrived in good condition, after passing into that arrived in good condition, after passing into sold at the prices quoted.

10. OUR GUARANTEE:

TVe guarantee to send:

(a) Healthy stock

(b) Free from insects, diseases, etc.

(c) Delivered in Good Condition.

Then our responsibility ceases. If we fail in these, we will:

(a) Replace with other stock of same value, or

(b) Refund the purchase price of stock in question. But it is mutually understood that we will not be liable for any greater amount or damages. If stock is not accepted on these terms, we should be notified at once, not over five days after receipt, and we will refund the money remitted and advise disposition of stock in question.
11. SUBSTITUTION. We desire to follow our customers' wishes in this respect and have found that when our supply of stock ordered is exhausted. our customers ordinarily want us to substitute to the best of our judgment. We, therefore, substithe best of our judgment. trary. Please note in specified blank on our Order trary. Please note in sish us to substitute in your Sheet if you do not wish us to substitute in your order and we will gladly refund for shortages, if is of first importance to us and our services to you can often be of more value, if you leave the selection to us.

12. NO AGENTS. We do not employ any agents or alesmen and have no connection with any other nursery. We deal direct with all our customers and are directly responsible to them and no one else. Many nursery men and dealers buy stock of us to re-sell. Such buyers re-sell the stock in their own account and responsibility.

13. SERVICE. We are so equipped that we can ret out, pack and ship most orders the first or second day after receipt of order. In some cases on account of character of stock, it may take loner. We leave most of our stock in the ground and dig fresh as wanted, so this takes longer to and dig fresh as was ready "ssemble an order than if the stock about two weeks "cellared." There is a period of about two weeks late in the spring, that we are rushed with orders from those who wait until the last minute. Under such conditions we will do our best to get out as quickly as possible but in order to be fair we will wait upon each order in its turn. It is better to order a few days or better, several days in advance of time stock is wanted; then we

point you with a tardy delivery.

14. SHIPPING SEASON opens November 1st and closes March 15th Will accommodate late orders after March 15th, if selections are still in stock and not too far advanced in new growth. Best
months in which to plant are November, December and February.

\section{DISTANCES FOR PLANTING}

Depending on character of soil, etc.

Peach, Plum, Apple, Apricot, 20 to 25 feet apart each way.

Pear, 20 to 30 feet apart each way.

Pecans, 40 to 60 feet each way.

Figs, 12 to 18 feet apart each way.

Haupt, McDonald and Dallas Berries, $3 \frac{1 / 2}{2}$ by

5 feet. In rich land 4 by 6 feet.

Other Blackberry and Dewberry, 3 by 4 feet.

Strawberry, 1 by $2 \frac{1}{2}$ feet.

Grapes 12 by 18 feet.

\section{NUMBER OF TREES OR PLANTS TO THE ACRE}

$1 \times 1$ foot, 43,560

$1 \times 2 \frac{1}{2}$ feet, 17,424

$2 \times 2$ feet, 10,890

$1 \frac{1}{2} \times 3$ feet, 9,680

$3 \times 4$ feet, 3,630

$3 \frac{1}{2} \times 5$ feet, 2,430

$4 \times 4$ feet, 2,722

$5 \times 6$ feet, 1,815

$10 \times 10$ feet, 435

$12 \times 12$ feet, 302

$12 \times 18$ feet, 201

$14 \times 14$ feet, 223

$16 \times 16$ feet $18 \times 18$ feet, 130 $20 \times 20$ feet, 108 $20 \times 25$ feet, 87 $25 \times 25$ feet, 69 $30 \times 30$ feet, 48 $30 \times 60$ feet, 24 $25 \times 30$ feet, 58 $40 \times 40$ feet, 27 $40 \times 50$ feet, 22 $50 \times 50$ feet, 17 $60 \times 60$ feet, 12

To determine number of trees to an acre for any given distance apart, multiply distance apart, and divide 43,560 by this product.

For example:

18 by 20 feet $=360 . \quad 43,560 \div 360=121$.

There are 121 trees per acre, planted 18 by 20 feet. 


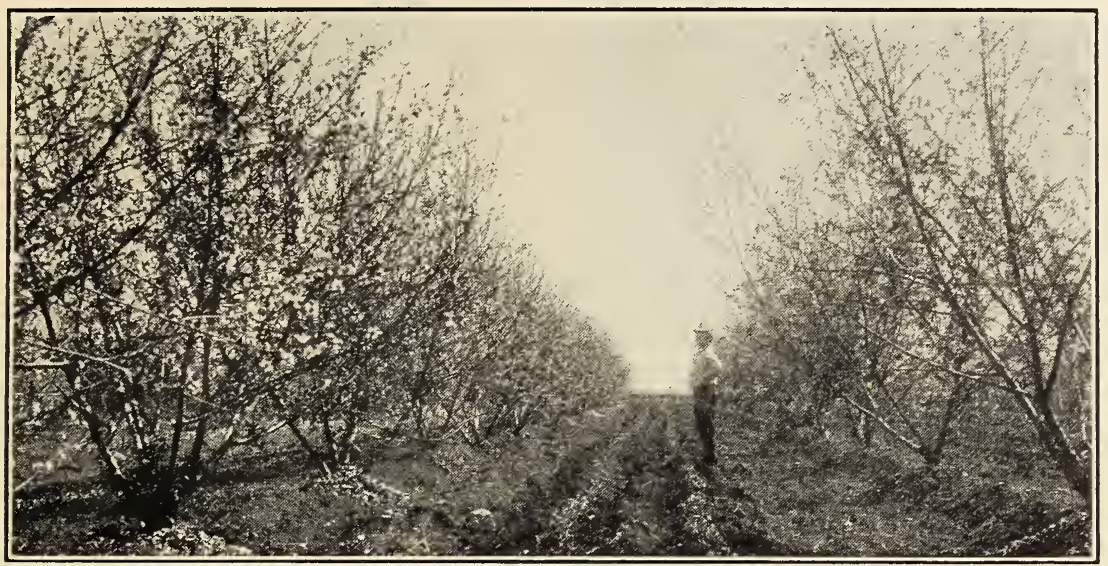

Peach Blossoms in March, 1927.

\section{FRUIT TREES Apples}

The Apple is not very profitably grown in Southern and Western Texas. There are a few varieties that grow, and only certain localities where these succeed. The latter are in the mountainous regions of Texas and Mexico. The best results are obtained on heavy clay soil. Light or sandy soil must be manured before apples can successfully be grown on same. The apple we grow in our state has a very fine aromatic flavor, more so than that grown in the North, and people who think their soil may be adapted to its culture should experiment with a few trees. Trees grown in the North should, however, never be planted; they will never prove a success. The following is a collection of those that I have found worthy of planting in the South.

PRICES: Strong 4 to 6 feet, 2 years old, grafted on whole roots, 50 cents each, $\$ 5.50$ per dozen, $\$ 40.00$ per 100 .

Delicious-Large, dark red, flesh is fine grained; crisp, juicy; very attractive and a great market apple; the tree is very hardy and a thrifty grower.

Jonathan-A great favorite; medium size; red and yellow; tender white flesh; juicy and rich; very productive.

Mammoth Black Twig-Large; bright yellow; shaded red; of good quality.

Red Astrahàn - Large; very handsome; Juicy; very hardy; a good bearer.

Early Harvest-Large; pale yellow; tender; with a fine flavor; a good grower and a heavy bearer; about the first to ripen.

Early Harvest-Medium, bright straw yellow. Tender flesh, sub-acid. Fine eating and cooking apple. Good for local market but rather tender for shipping.

Red June-Tree slow grower but bears young. Small to medium size; bright red skin; flesh tart and quality good. Fine table and market; best shipper of extra early varieties.
Arkansas Black-Vigorous, abundant, dark red, medium; excellent market; seedling of Winesap.

Kinnaird's-Strong, spreading tree, prolific; red, large; a superb Southern Winter apple; the best of all Winesap seedlings. Flesh pale yellow, crisp, fine grained; of fine quality; tree longest lived of all varieties tested with us; originated in Tennesseo

\section{Crab Apples}

Price, two-year-old trees, 50 cents each, $\$ 5.50$ per dozen,

This pretty apple is especially adapted for preserves and is always sure to bring a good crop.

Transcendent-(Siberian.) An attractive yellow color, splashed and striped with red; bears very young, annual crops thereafter. We value it highly for preserves. Buds and blossoms exquisitely beautiful. Ripens in July. 


\section{Pears}

2 to 3 feet high, 35 cents each, $\$ 4.00$ per dozen; 4 to 5 feet high, 50 cents each, $\$ 5.50$ per dozen; 6 to 7 feet high, 75 cents each, $\$ 8.00$ per dozen.

In order of ripening. One and two-year-old trees.

The pear is the most profitable fruit we know of. After a tree has once begun to bear, it will bear regularly every year. The tree is very long-lived if it has a favorable locality where it can send its roots deep into the ground for a supply of moisture; for this reason pear trees should only be planted where the sub-soil is rich and deep.

The soil most adapted to pear culture is rich loam, which contains a good supply of humus. Sandy soil with clay sub-soil is also good if well manured. Pear trees should however, never be planted on soil where roots of cotton and potatoes rot, as such soil has the same effect upon pear trees. The following are the best varieties:

Summer Beauty-First raised in 1873, and introduced in 1893 by us. This pear is the finest and the surest bearer of all varieties that ever have been tested so far south. The trees have not failed to produce heavy crops every year since 1880 . It is a vigorous, symmetrical grower and late bloomer so that spring frost will not injure it. The fruit is very large and handsome, of yellow color with a bright red cheek, flavor sweet sugary, rich, aromatic and pleasant, excellent quality, always grows in clusters of from three to five. One of the rarest and most productive pears in cultivation. Ripening the end of July.

Le Conte-Of remarkable vigor and beauty of growth. The fruit is bell-shaped, of a rich, creamy yellow when ripe, very smooth and fine looking, and a good shipper.

Bartlett-Standard and dwarf. Everyone is acquainted with this large yellow pear. Fruit very rich and highly aromatic-the reason why this pear can always be sold while others may be refused. Tree grows dense and of even and conical shape.

Keiffer Hybrid-Called by many the "Queen of Pears." Fruit large to very large, skin yellow with a brilliant vermilion cheek, flesh brit tle, very juicy, with a marked musky aroma. Tree very vigorous and very prolific. Consid. ered the best all-around pear.

Garber Hybrid-Oriental strain, like the Smith's fruit resembles the Kieffer in size, shape and color; ripe three weeks before.

Chinese Sand-Called the "Pineapple Pear." Valuable for the South as a canning pear. Flesh is coarse, about the quality of Kieffer. Tree a good grower, not subject to blight; good bearer. Ripens August.

\section{Apricots}

One-year trees, 4 to 6 feet, 50 cents each, $\$ 5.50$ per dozen. Strong 3-year old specimen trees, each 75 cents.

The apricot is one of those fruits that do fairly well on limestone soil; a rich, heavy soil. however is preferred. As the apricot blooms early it should not be planted extezsively in localities visited by late frosts. The fruit is much beloved for its rich and azomatic flavor,

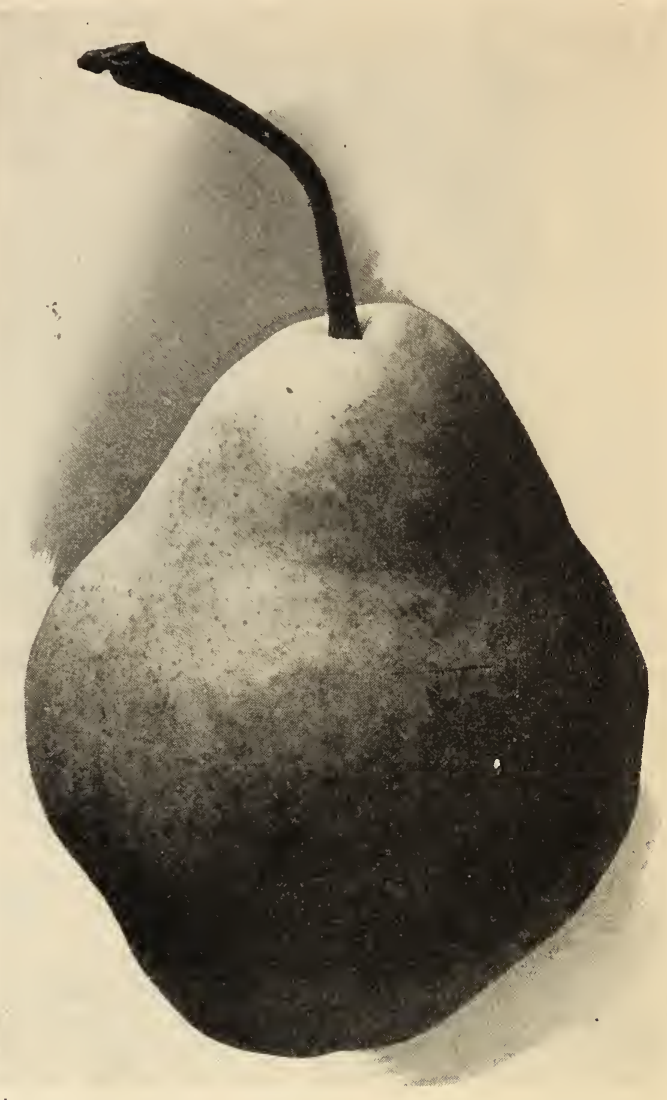

and the apricot should be represented by a few trees, at least, in every garden. The culture is about the same as that of the peach.

Royal-Fruit large, oval; color of skin dull yellow, tinted with red on the sunny side; flesh pale orange color, firm, juicy, rich and vinous; freestone. Ripens end of June.

Moorpark-Large, excellent; an old favorite and one of the best bearers. This is the best of all apricots.

\section{Quinces}

50 cents each, $\$ 6.00$ per dozen.

The Quince likes a rich, deep, moist and at the same time loose soil, and requires careful cultivation. The fruit is only used in a cooked state and it is a great favorite with the housewife owing to its rich aroma, which makes it fit for all kinds of preserves and jellies.

Orange-Large, roundish, bright golden yellow; cooks tender and is of excellent flavor. Valuable for preserves and flavoring; very productive; one of the most popular and extensively cultivated of old varieties. Ripens in October.

Champion-Fruit very large, fair and handsome. Tree very productive, bears when young; flesh cooks as tender as the apple; flavor very delicate, imparting an exquisite taste and odor to any fruit with which it is cooked. 


\section{Pecans}

$2 \mathrm{ft}$ at $75 \mathrm{c}, 3 \mathrm{ft}$. at $\$ 1.00,4 \mathrm{ft}$. at $\$ 1.50,5 \mathrm{ft}$. at $\$ 1.75,6 \mathrm{ft}$. at $\$ 2.00,7 \mathrm{ft}$. at $\$ 2.25,8 \mathrm{ft}$. at $\$ 2.50,10 \mathrm{ft}$. at $\$ 3.00$.

Dozen rates, price of 12 trees less $10 \%$. One dozen $\$ 1.00$ trees would be $\$ 11.00$, etc.

This is by far the choicest table nut that is grown in America. Each year the demand is increasing; the supply can never equal the demand for good nuts. They are a healthful, nutritious article of food. Plant a tree if you have only a small place, and a thousand trees if you have the land for them. You can count on a good income for your children and your grandchildren. The pecan tree grows on any deep soil, clay with gravelly sub-soil preferred. If you have a river bank that washes badly and you want to make this ground valuable, we can enlighten you, by advising to plant it in a pecan orchard; after the trees are 4 to 5 feet high plant the ground in Bermuda grass for sod, and you have more than doubled the value of your land. If it's a shade tree you want to plant this winter, stop and think it over; why not plant a pecan tree?

Burkett-Callahan County. Large, almost round, shell thin. Flavor excellent. One of the best. Bears young and every year, fine.

Curtis-A vigorous grower and a young and prolific bearer. Nuts are just below medium size, but of high quality. Well adapted for planting in the southern states.

Delmas-Nut large, shell moderately thin; quality very good, flavor excellent. Tree quite vigorous. Quite successful in Central to North Texas.

Halbert-Coleman County. Almost round, medium size. Flavor highest. Perhaps the youngest bearer known. Prolific. An allaround pecan. Very thin shell.

Money Maker-Tree of healthy and vigorous growth; bears at early age and is prolific. Nut of medium size and fair quality. Adapted to the entire pecan belt.

Moore-A vigorous grower of handsome appearance. It begins to yield at an early age and is the first to mature nuts. It is an un. usually heavy yielder and is a regular bearer of medium sized pecans, oblong and good cracking quality. Adapted to a wide range in the pecan belt.

Pabst-A vigorous and healthy grower with large, handsome foliage. Nuts large, filled well and are of good quality. A standard and highly recommended variety.

Lone Star-Seedling of the Daisy pecan Larger and thicker, slightly harder shell; - a wonderful bearer, fills well, a fine grower, large leaves, same as its parent, the Daisy.

"Daisy"-Takes the first place of all com mercial nuts; is not only the largest paper shell in existence, but it is well filled, of a fine, sweet flavor; a regular bearer and it has not failed to bear a good crop since it first began in 1894 .

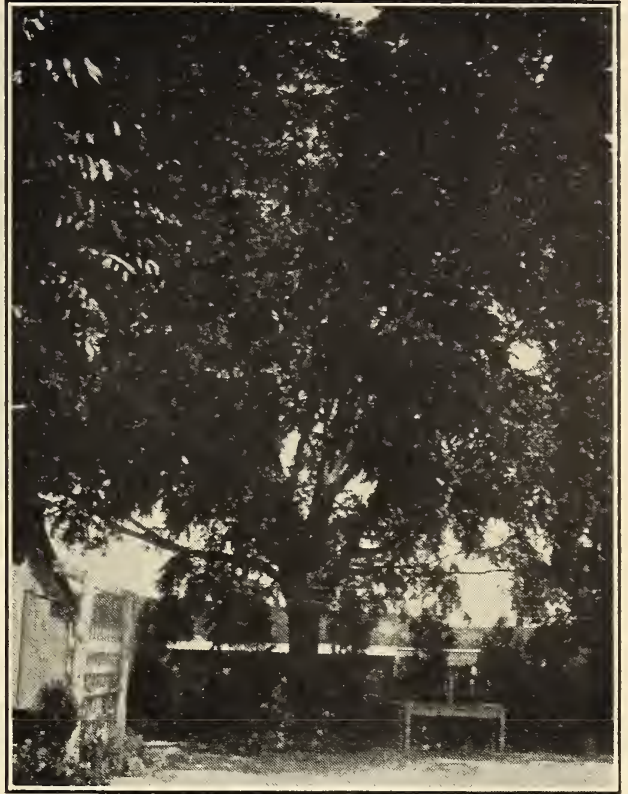

Daisy Pecan Tree Twenty Years Old. 204 Pounds of Pecans Last Year.

Frotscher-A large oblong nut, bright yellowish brown in color, with a few purplish black markings, shell very thin, cracking easily, kernels large, easily removed, full of good quality. One of the handsomest nuts grown.

Schley-Size medium to large, oblong, somewhat flattened; light reddish brown with a few markings of purplish brown; shell thin, separ. ating easily from the kernel, kernel full, plump, bright yellowish brown in color, flavor rich nutty, in quality one of the best. Tree a good grower and an excellent variety.

Stuart-One of the oldest of the named va rieties, but somewhat short; ovoid in shape, shell thin, partitions somewhat corky, kernel plump, quality very good.

Success Pecan-Originated in Southern Mississippi. Large size, shell thin, kernel very plump, quality good, flavor good; highly prolific; one of the very best and most promising sorts.

\section{Walnuts}

Juglans Cordiformis-Nuts medium size, thin shell; if cracked longitudinally kernel can be removed entire. Meat is of good quality; tree is a vigorous grower and forms a fine head. Perfectly hardy. We consider it the best of all walnuts. Two years, 2 to 3 feet, $\$ 1.00$ each, $\$ 10.00$ per dozen.

Juglans Sieboldiana-A native of the mountains of Japan. Extremely hardy and vigorous grower. Three-year-old trees have produced nuts. Wonderfully productive. Meat sweet and of best quality. $\$ 1.00$ each; trees 2 to 3 feet, $\$ 10.00$ per dozen. 


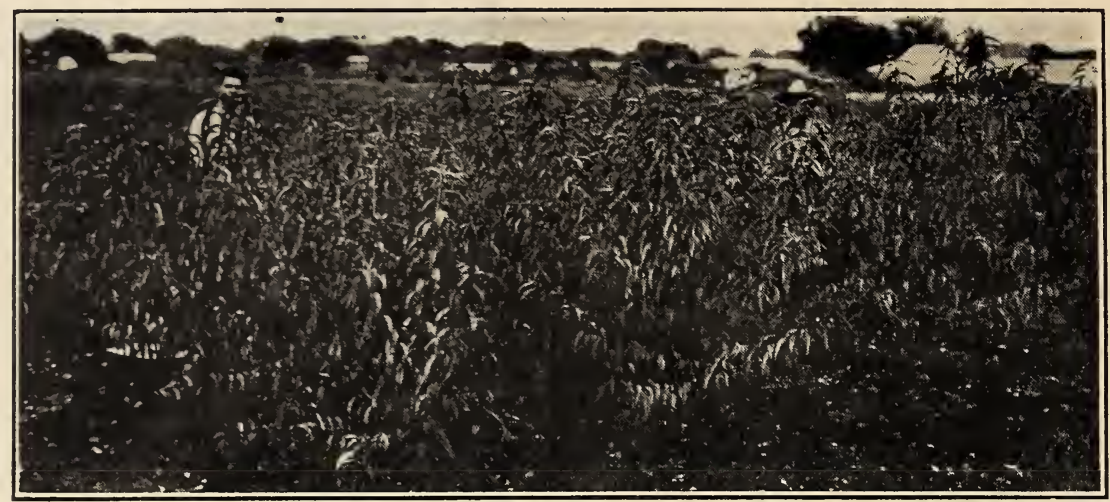

One Year Peach Trees in June.

\section{Peaches}

Prices, except where noted, 2 to 3 feet, 25 cents each, $\$ 2.75$ per dozen; 3 to 4 feet, 35 cents each, $\$ 3.75$ per dozen; 5 to 6 feet, 50 cents each, $\$ 5.50$ per dozen. Strong 3-year specimen trees, each 75 cents.

The peach is probably more extensively cultivated in our country than any other fruit, and it well deserves its popularity among the American people, as there is nothing that excels a luscious, red-ripe peach. There has, however, been much complaint of late that the finer varieties do not bear enough in Texas. People attribute this to the drought, yet the failure in most cases is due to the ignorance of the people. The traveling tree agents from other states introduce new varieties every year that are in most cases not at all adapted to our climate. Therefore, never buy a tree unless you know that it was grown by a reliable nurseryman in your own state. West Texas is a dry country, but nevertheless good peaches can be raised, and plenty of them, provided proper varieties are planted.

The peach succeeds in almost any soil, but it prefers sandy soil with red clay sub-soil to any other. The following varieties are all thoroughly tested by me, and I consider them the best collection that can be made for our climate. They are selected from 400 different varieties, and as each variety has a ripening period of from ten to fifteen days, peaches may be had at all times from the middle of May until November. I have arranged them in order of ripening, for the convenience of the buyer.

\section{Ripening Here from May 20 to June 10 .}

Mamie Ross-A seedling of Chinese Cling. Fruit very large, nearly covered with a delicate carmine, flesh white, juicy and of good quality; a regular and prolific bearer.
Mayflower-A new variety of extreme early ripening; a late bloomer, and being almost entirely covered with red, it is a good market variety. Tree a strong thrifty grower, very prolific; size large, nearly round.

Victor-Larger than Mayflower but not so highly colored; very sure and prolific; white; nearly free.

Early Wheeler-Prolific; white, blush cheeks, flesh white, extra firm, of better quality than Alexander, with true clingstone flavor. The best shipper among early varieties.

Dwarf Japan Blood-Tree of dwarf habit, surest bearer of all the early peaches; fruit is large, pointed; red cheek and end, and sometimes blood-red flesh.

Alexander-Good quality, high color; flesh greenish white. Best bearing May peach.

Greensboro-Earlier and larger than Alexander; fine flavor and attractive appearance.

Arp Beauty-A rival to Elberta; character, size, color and quality the same, and ripens two to three weeks earlier. The value of this as a market and family peach will be easily seen, and no other statement will be necessary to place it at the head of good peaches.

Triumph-“The earliest yellow peach in the world." A perfect yellow freestone; of excellent quality. Ripens after Alexander. A good keeper, very prolific. Two-year-old trees bore half a bushel each.

Honey-The sweetest of all peaches we have, and about the best bearer. Late frosts have never killed the voung fruit here. Color is at tractive and it always sells easily. Honey is about the best peach for general planting we have in the South and the Gulf Coast.

Indian Cling or Blood Cling-Red inside, ripens in August, bears regular, trees very hardy; a good peach.

Bokara-The hardiest peach known. It is of fine quality and a good bearer. Does remarkably well here. 


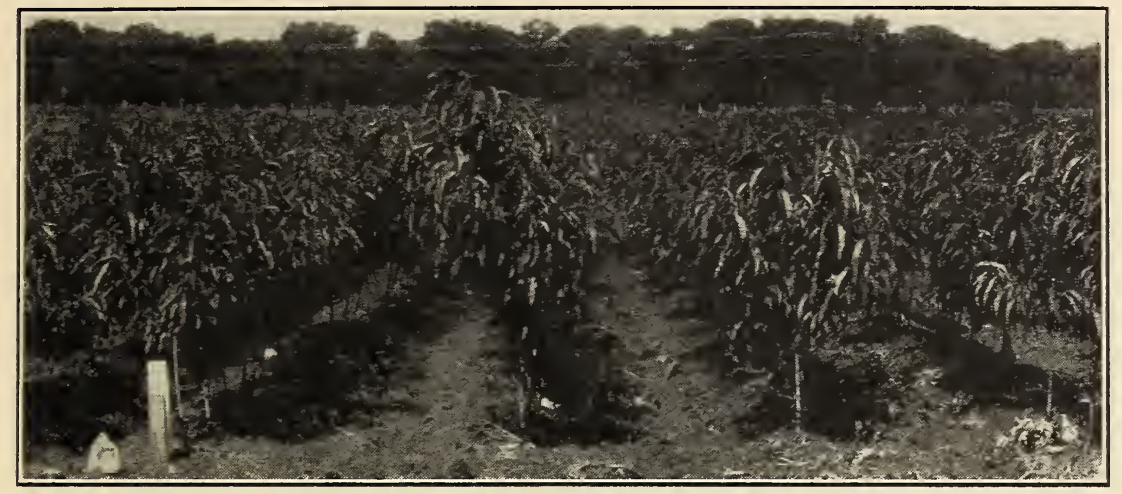

1 Year Peach Trees.

\section{Ripening June 20 to July 15.}

Pallas-Large, flesh white, melting with a rich, vinous aroma; profuse annual bearer; as sweet as Honey peach.

Carman-A large, white free-stone with red cheeks, that originated in Limestone County. Fine flavor; ripens July 5.

Early Bell-Very large; skin white, with red cheeks; flesh white, firm and excellent flavor; tree a rapid grower and very prolific; a seedling of Chinese Cling.

Dixie-A seedling from Elberta; large; two weeks earlier and a better shipper. Fine flavor; beautiful color, yellow with pink cheeks. Tree is a fine grower and the best bearer in San Marcos, Texas, where it originated. A gentleman working in the Wood National Bank bought a peach many years ago, and it being of such fine flavor and large size, he pianted the seed just back of the bank building, where it grew vigorously, and after bearing, everyone seeing it was astonished at the size and good color of the fruit, as well as the productiveness of the tree. Mr. F. M. Johnson sent us the first buds and named it the "Dixie" peach. We find it to be superior to Elberta in flavor. It is the finest peach that ever originated in Southwest Texas. Peach is yellow like Elberta.

Leona-Best yellow free stone peach, ripens week earlier than Elberta, large, good grower.

J. H. Hale-Huge; beautiful golden yellow; freestone; solid; delicious; round as a ball; a great shipper; a splendid keeper; brings top prices and big prices; vigorous, sturdy trees. No orchard complete without this peach.

Belle of Georgia-Very large, white freestone of excellent flavor. Trees grow and bear well; fruit a very good shipper.

Elberta-The peach that everyone knows. A large yellow free-stone, red to the pit. The peach for the market.

Southern Early-This is the largest of all early peaches. Good quality; very prolific; sweet and juicy. Ripens in June.

Augbert-Yellow, resembling Elberta; ripen. ing later; more prolific and fruit is of highest quality. Sometimes called late Elberta.
Old Mixon Cling-The juiciest and best flavored white cling-stone peach; of very large size and best bearing qualities.

Hero-A splendid variety for canning purposes. The tree grows to a very large size and produces beautifully colored, white fleshed. juicy clingstone peaches in great abundance; sure to bear every year; flowers very resistant against frost.

Chinese Cling-Spreading habit; healthy; not very prolific; the largest peach in cultivation; flesh white with little red at seed; tender, very juicy.

\section{Ripening from September 1 into October.}

Henrietta-The best late clingstone. Very large, yellow, crimson cheek; a regular bearer.

Mathews Beauty-Large, light colored yellow, of best buttery flavor. Skin yellow ground with red cheek, making it a very handsome appearing peach. Freestone.

\section{Plums}

In order of ripening. Prices, except where noted: 2 to 3 feet, 30 cents each, $\$ 3.25$ per dozen; 3 to 4 feet, 40 cents each, $\$ 4.50$ per dozen; 5 to 6 feet, 50 cents each, $\$ 5.50$ per dozen. Strong 3-year specimen trees, each 75 cents.

There is no fruit tree that bears such an abundance of fruit at so early an age as does the plum. Many varieties bear the first year after planting, and for this single reason should be most extensively planted. A plum tree requires very little care, but for the fact that it produces its fruit in such great abundance the tree does not live very long, and new trees ought to be planted every year to always have an abundance of this useful fruit. The American or Chickasaw varieties are mostly used for preserves and jellies, while Japanese varieties are for the table.

Rich loam with gravel sub-soil is the best soil for plum culture, while sandy soil is almost as good if manured.

The following is the best collection for the South and cannot be excelled by any:

McCartney-Originated in Texas; larger than Wild Goose; 14 days earlier; egg-shaped, golden yellow color; enormous bearer. This is the best yellow plum. 


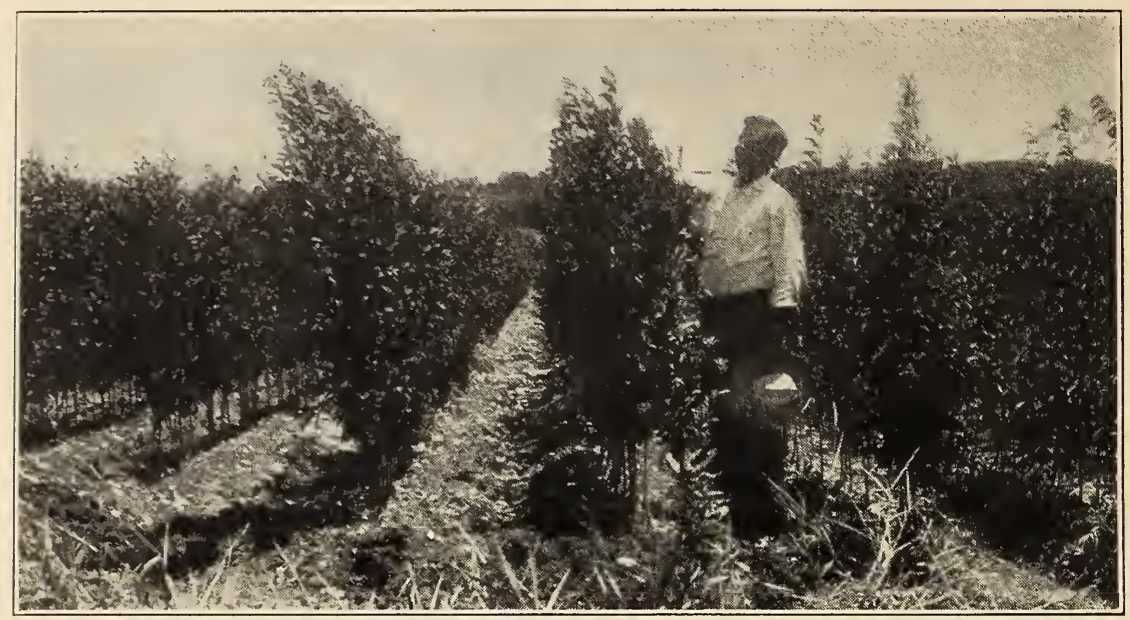

1 Year Plum

Shiro-A combination of Robinson, Myrobolan and Wickson. Rank grower, enormously productive; fruit will keep a month, and is so transparent the pit can be seen through the flesh; apple-shaped; the earliest of all Japanese plums.

Gonzales-A cross between the American and Japanese plum. The fruit is larger than a Botan, it is sweet and juicy and will keep for a week after ripening. The tree is a good grower and is very prolific. It ripens the middle of June.

Happiness-A new hybrid. The fruit is very large, color glowing red, and in quality it is rarely equaled. It is really the most productive of all plums. Tree is a good grower. Pit very small. Three-year-old trees averaged $\$ 5.00$ per tree this year, as this variety was not damaged by the late frost last spring.

Nona-Large, oblong, red cheeks; heavy bearer; meat yellow and very sweet; ripens in July; tree a healthy grower and long lived. One of the best plums for market.

Mikado-We are very glad that we can list this fine Japanese plum again. Shape round like an apple, yellow meat, very firm; fine shipping and the best plum for the market gardeners. One of my oldest customers said he planted this plum from our nursery thirty years ago and the first trees are still bearing.

Sultan-Japanese, very large, purplish red, flesh red, very sweet, juicy, and one of the best red plums.

Gold-Medium sized round plum. Meat firm; good shipper; bright golden yellow color.

Bartlett-Has the quality and flavor of the Bartlett pear. Fruit turns a deep crimson when fully ripe, light salmon colored flesh. Tree has a beautiful upright growth.

Sweet Botan-Japanese; one of the finest and oldest varieties which is too popular to need a long description.

Wickson-Japanese; tree grows in vase form, sturdy and upright. The fruit is evenly distributed all over the tree. It changes to white when about half grown, and remains so until a few days before ripening, when it changes to a glowing carmine. Small stone; the flesh is of a fine texture, firm, sugary and delicious and will keep two weeks after ripening. A fine rare plum.

The Santa Rosa-No one fruit has so strongly individualized the name of Luther Burbank as the plum. His latest, the Santa Rosa, is in every way not only a superior fruit from every point of view, but must be regarded as the best thing in the way of plums that has come from his hands. The Santa Rosa is a medium bloom. er; quality of fruit is unequaled; as a shipping plum it is the peer of them all. Plums are a deep purplish crimson, each fruit averaging 6 inches in circumference each way; the flesh near the skin is purple shaded with rosy scarlet and pale amber towards the stone, which is very small; the eating quality is unequaled; rich, fragrant, delicious. Ripens a week before Climax and two weeks earlier than the Burbank. Tree is strong, vigorous, upright grower.

Burbank-Japanese; named after the introducer of this and most of the other good plums. The best bearing variety we have. When fully ripe the fruit is deliciously sweet.

Satsuma-A large and well flavored pium with blood red flesh, skin bluish red, pit is very small; trees grow large and old, and is a very good bearer.

Bruce-June 5. Large red, productive. A hybrid. One of the best plums. Originated with Mr. A. L. Bruce of Donley County.

Excelsior-Fruit medium, sweet, juicy, melting, color reddish purple; a good plum and very productive.

Compass Cherry-In size larger than the larg. est cherry; rather a small plum. It will succeed where the true cherry will not. The tree is vigorous and bears well; fruit is red; fine for jellies and preserves; ripens in June.

\section{Prunes}

Large California Prunes. Trees 4 to 5 feet, 75 cents each. 


\section{Mulberries}

5 to 6 feet, 40 cents each, $\$ 4.50$ per dozen. 6 to 8 feet, 50 cents each, $\$ 5.50$ per dozen.

As a shade tree for the chicken yard the mulberry is about the best to be had. Chickens eat the fruit as soon as it drops from the tree. The finer varieties are also eaten by children. The tree grows very quickly and is easily transplanted.

Hick's Everbearing-Profuse; ripens three months; fine grower for shade and the best of all trees for the fowl yard.

Russian-Unquestionably the best shade tree. The tree is very hardy and long-lived. and grows rapidly to a beautiful round shape. The fruit is small and does not drop from the tree when ripe; some trees do not produce fruit at all. It is very much sought for street planting, for the shining leaves stand the dust well.

English-A very quick growing mulberry, with very large and well shaped leaves. The fruit is large and black of color; stem is very straight, and can be topped at any desirable height. 4 to 5 feet, 35 cents each, $\$ 3.50$ per dozen; 6 to 8 feet, 50 cents each, $\$ 5.00$ per dozen.

Travis-(Everbearing). Luxuriant, symmetrical and compact. Best of all mulberries for fruit. It is very large and sweet, and bears in greatest profusion. The original tree stands in Travis Co.

\section{Japan Persimmons}

(Diospyros Kaki)-A fruit from the Orient that has come to stay. The growing of this fruit in the South, both for the market and home consumption, is no longer an experiment. It has proven itself adapted to the whole cotton belt, and is becoming quite popular on the northern fruit market.

Trees of the native persimmon will grow on any soil in the South, but are not long-lived in wet, low places; high, well-drained, sandy soil suits them best, and they will do better on very poor land than any other kind of fruit tree. They are especially suited for planting in old peach orchards, as the old trees become worthless, or to replant the land after a peach orchard has been destroyed.

Fruit should be shipped just before it begins to soften, and directions how to eat it should be printed on wrappers to be used with each fruit, and dealers instructed to display only ripe fruit.

Price of Japanese Persimmons on native Persimmon Roots, 50 cents each, or $\$ 5.50$ per dozen, $\$ 40.00$ per 100.

Hachiya-Very large, oblong, conical, with a sharp point; very showy; diameter $3 \frac{11}{2}$ inches longitudinally and 3 inches transversely; color of skin reddish yellow, with occasional dark spots or blotches and rings at apex; flesh dark yellow; some seed; astringed until fully ripe, then very good. Tree vigorous and very shape 1y.

Hyakume-Large to very large, varying from roundish oblong to roundish oblate, but always somewhat flattened at both ends, generally slightly depressed at the point opposite

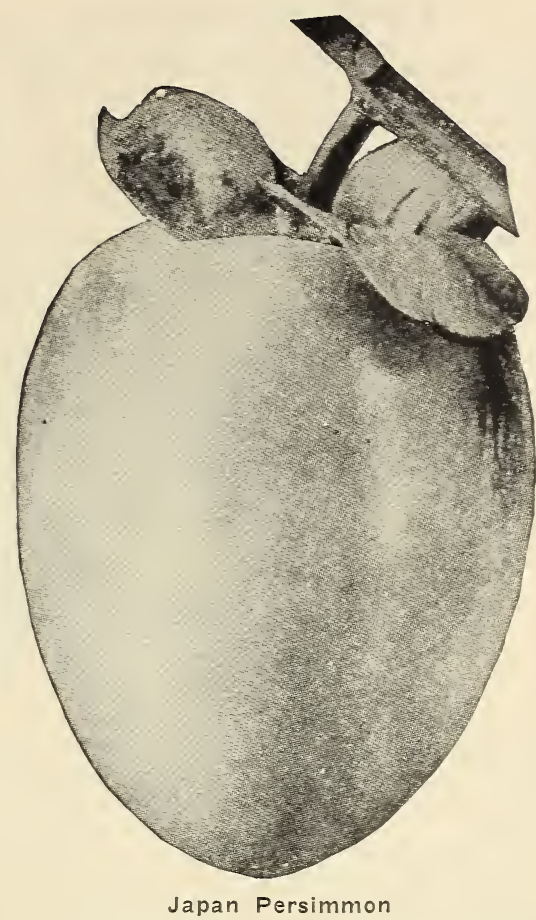

the stem; nearly always marked with rings and veins at the apex; skin light buffish yellow; flesh dark brown, sweet crisp and meaty; not astringent; good while still hard; a good keeper; one of the best market sorts. Trees of good growth and sure bearer.

Triumph-Originated near Sanford in Orange County, Florida, from seed from Japan. Its quality is the best, size medium, tomato. shaped; color of skin dark red, handsome and showy, flesh with but few seeds. It is very productive, the fruit of a single tree having been sold for $\$ 17.00$. Ripe in October and holds on the tree until January.

Tane-Nashi-Very large, roundish, conical, pointed; very smooth and symmetrical; color of skin light yellow, changing to bright red at full maturity; flesh yellow, generally seed. less, astringent until fully ripe, then one of the best.

Yemon-Large flat, tomato-shaped, somewhat foursided; diameter $2 \frac{1}{2}$ inches longitudinally and 3 inches transversely; very smooth and regular in outline; skin bright orange yellow, flesh yellow, generally seedless, quality very fine. Tree rather an open grower with distinct foliage of light shade.

\section{Nectarine}

Honey-In a lot of trees grown from Nectarine seed, one we call Honey is superior on every point. It has the sweetness and bearing quality of its grand parent, the Honey Peach. It does not rot. Ripe July. $4-5 \mathrm{ft} ., 50 \mathrm{c}$ each; $\$ 5.00$ per dozen.

\section{Grape Fruit}

The increase in cultivation, production and use of the Grape Fruit is without parallel in American horticulture. We have the best seed. less variety. 1-year trees $\$ 1.00$ each. 


\section{Pomegranates}

The Pomegranate seems to have been created especially for our dry climate. It succeeds in any soil and bears regularly an abund. ance of the most refreshing fruit.

Little trouble is required for its culture. It is always free from all diseases, and grows in any deserted corner of the garden where no other fruit succeeds. The fruit is very sweet and refreshing, and ripens during August and September.

Old Favorite-Is the best of all the fruiting pomegranates. I call it Old Favorite because it has been grown here at New Braunfels for at least fifty years, and it has been proven to be far superior to all the other fruiting kinds which were introduced later. The fruit is the very largest, refreshing and sweet. The tree

\section{Grapes and Berry Plants}

\section{Grapes-Standard List}

In succession. Finest quality. This list contains the best and most successful. 20 cents each, $\$ 2.00$ per dozen, $\$ 18.00$ per 100 , except where noted.

The grapes thrive in almost any soil and are successfully grown all over the South. With but little skill and labor they bring abundant crops every year. The following are the best southern varieties.

Ladano-Hybrid of Salado and Headlight; vine vigorous, healthy; foliage similar to that of Headlight; cluster medium, compact; berry translucent, round; skin thin, tough; pulp tena $\rightarrow$, melting, rich, pure and sweet; seeds few; nne for hot climate and limy soils.

Volney-Clusters very large; berries large and slightly oval; a week later than Ellen Scott; violet color.

Muench-Vine, very vigorous and free from all diseases; clusters large to very large; purplish black; sells readily in the market; fine for table.

Lomanto-Vine vigorous, prolific; no rot nor mildew; leaf medium, dark purple or black color of grapes; excellent quality.

Ellen Scott-Vine beautiful, healthy, prolific; clusters large to very large, conical; berry large, translucent, violet covered with a delicate bloom; skin thin and tough; pulp tender, very juicy and pure; high quality.

Edna-Finest white grape in Texas. A tested variety gave largest crops regularly of any white grape ever introduced. No vineyard com. plete without this wonderful white grape. Very hardy one year strong plants, 25 cents each, $\$ 2.50$ per dozen.

Brilliant Grape-Growth strong; vines endure winters anywhere. Clusters large, cylindrical, or somewhat conical; berries large, light to dark red, translucent, with a thin bloom; very handsome when well ripened; skin thin, rather tender but seldom cracks; pulp meaty yet very tender, melting and delicious. or shrub is extremely hardy and has glossy green leaves. Flowers are large and crimson color. 50 cents each.

\section{Oranges}

Satsuma-Best hardy variety. One-year-old, $\$ 1.00$ each; $\$ 11.00$ per dozen; $\$ 85.00$ per 100 .

\section{Lemons}

The "New Wonder" Lemon is a true everbearing variety. On a plat six feet high, not less than 90 lemons were growing at a single time. Fruit has been taken from this tree weighing 4 pounds. It is not uncommon to make twelve lemon pies from one lemon. Will fruit freely the second year. Field grown, 1 year; 75 cents each, $\$ 8.00$ per dozen.

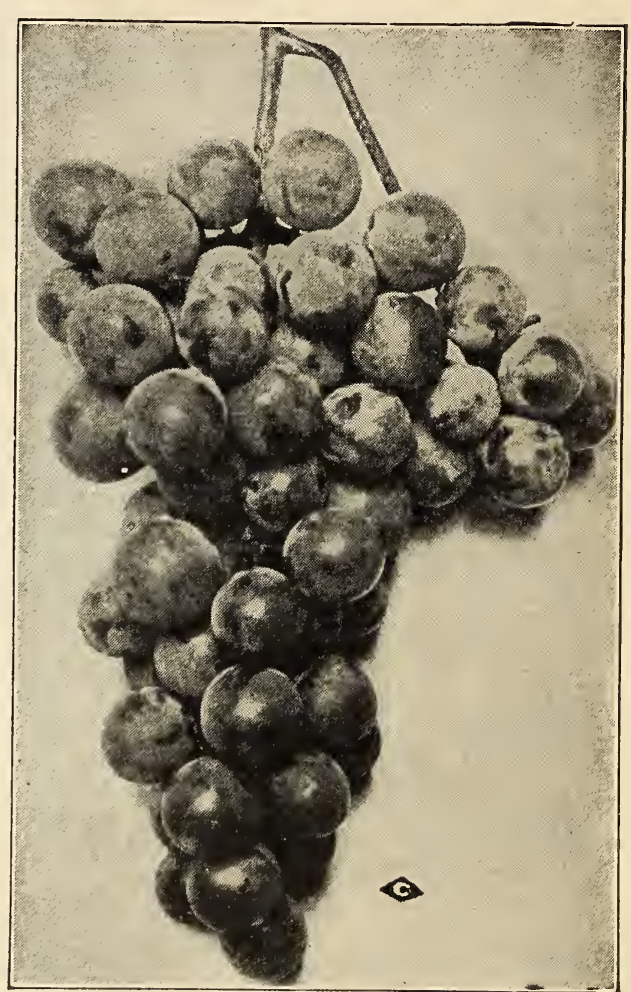

R. W. Munson-Growth strong; clusters medium to large, cylindrical, often shouldered; berries black, never crack; pulp tender, juicy, very fine quality; good wine grape.

Mustang Grape-1 year from seeds, 15 cents each, $\$ 1.50$ per dozen, $\$ 12.00$ per 100 .

Jacques-(Black Spanish, Le Noir, Blue French); berry small; large clusters; black; red wine.

Herbemont-(McKee, Bottsi, Brown French.) Small; large clusters; purple; finest quality; table, wine; best old grape in Southwest Texas.

Thompson Seedless Grapes-2-year; strong. $25 \mathrm{c}$ each, $\$ 2.50$ per dozen. 


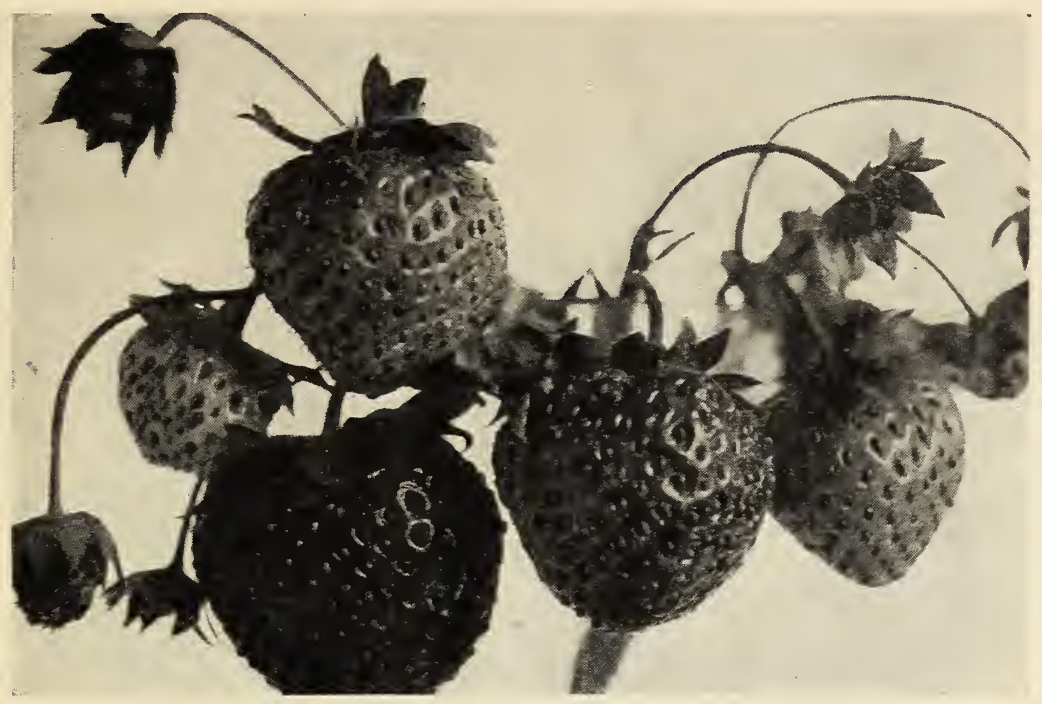

\section{Dewberries and Blackberries}

\section{IN SUCCESSION}

Prices 35 cents per dozen, $\$ 2.50$ per $100, \$ 15.00$ per 1000.

The Blackberry is not so successfully cultivated in our part of the state as it is in North Texas, but the Mayes Dewberry reaches its greatest perfection here. It produces fruit of enormous size, of good flavor and in great abundance. Every lover of berries ought to have it.

Austin's Thornless Dewberry-We gave this variety a thorough test and find it to be thornless, a good bearer and easy to pick; large berries of uniform size. It is all that the intro. ducer claims it to be and we recommend it to our customers, $\$ 1.00$ per dozen, $\$ 7.00$ per 100 , $\$ 50,00$ per 1,000 :

Mayes' Dewberry-New; very large, highly flavored. It roots deep, is very prolific and never fails.

McDonald Berry-It is hard to decide whether this is a dewberry or blackberry. It bears in clusters like a blackberry, but tips like a dew. berry. It grows on any soil and is the most productive of all berries. Berries are large, juicy, and of the best quality.

Corey Thornless Blackberry - 2-year. 20c each, $\$ 2.00$ per dozen.

Dallas-(Blackberry.) Very vigorous, drooping, thorny, productive; large, fine.

\section{Strawberries}

Prices 15 cents per dozen, $\$ 1.00$ per 100 , $\$ 8.00$ per 1000 .

To grow Strawberries with success irrigation is required in Western Texas, but where water may be had plentifully it is very valuable, being about the first fruit in spring.

Klondyke-The plant is exceedingly vigorous, seems to be absolutely rust proof, and as near drought proof as a variety can be. Every berry is firm and brilliantly colored. This makes it the greatest and safest money-maker. On good or well manured soil it is simply wonderful.

Lady Thompson-A great favorite with all growers. Mid-season; fine large berries.

Texas-The money making strawberry of the South. Besides being an immense producer of fine flavor and beautiful color, it is a thrifty grower and a splendid drought resister. Dur. ing the hot summer months we often lose our strawberry plants; the Texas strawberry, how. ever, is perfectly hardy and stands the heat well.

\section{Figs}

35 cents each, $\$ 3.50$ per dozen; $\$ 30.00$ per 100. Strong trees.

We might also say there is no tree which so abundantly repays its owner for the little trouble it requires as the fig. From June to October ripe fruit may be had almost daily from the same tree, providing there is enough moisture to constantly keep the tree growing during this time. The best place for a fig tree is near a well or a spring or any other place where there is always a plentiful supply of water. During extreme cold weather figs some. times freeze to the ground, but they sprout from the roots again in the spring. This, how ever, only happens every ten or fifteen years, if only the hardiest varieties are planted.

Green Ischia-Green; medium size; of excel. lent quality.

Magnolia-Large; rich fruit, yellowish brown. Hardy here. Small one-year trees bear fruit first summer.

Brown Turkey-Medium, brown, very sweet and excellent; very prolific and hardy. The most reliable fig for open field culture.

Celestial-Small pale violet; very sweet; prolific, hardy. 


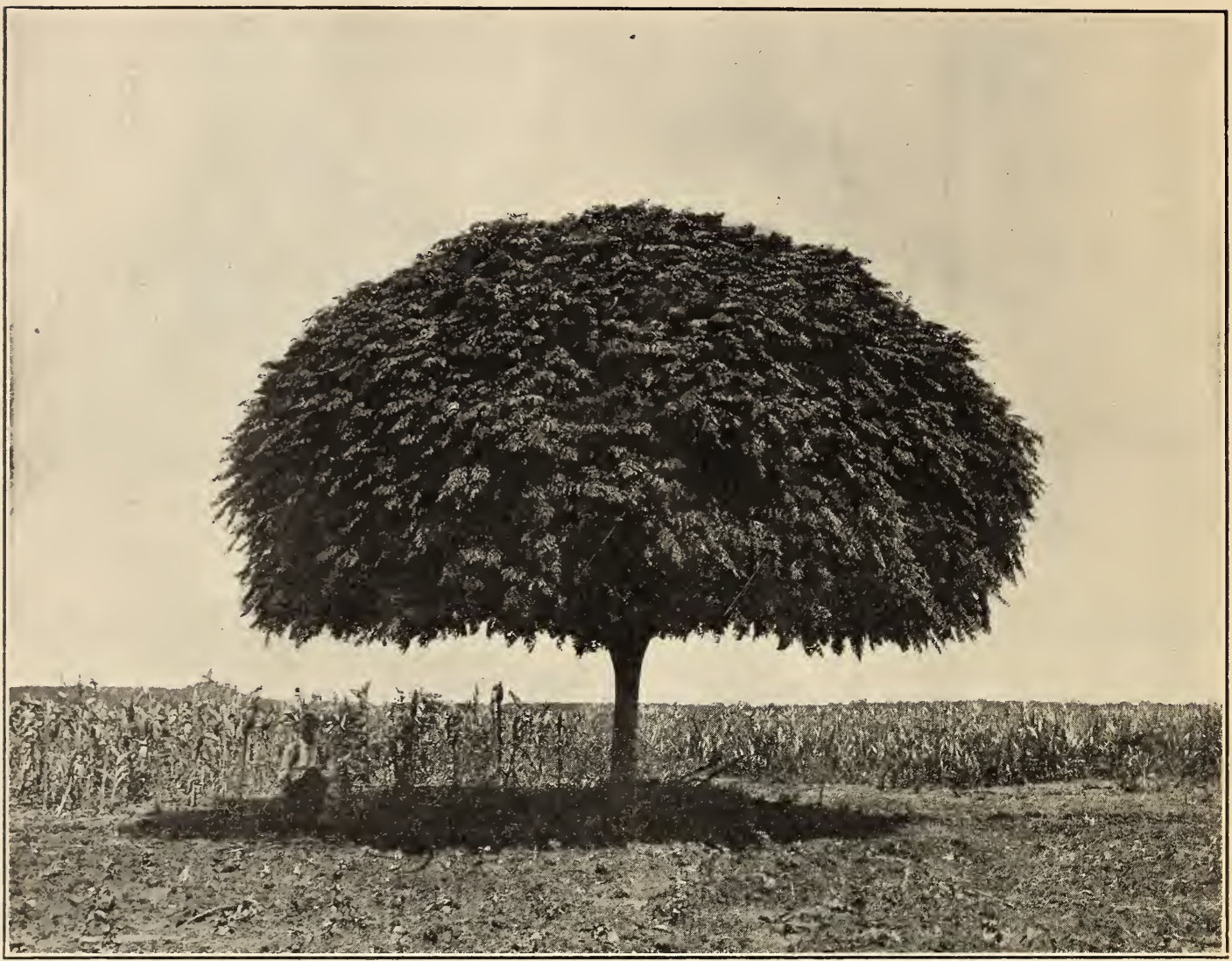

\section{Shade and Ornamental Trees}

All shade trees are nursery grown, are straight and have splendid roots.

The physical welfare of yourself and those that you hold dear is greatly advanced by the trees and plants which surround your home What a deserted impression does a splendid bouse make if not a tree or plant is near, and what a pleasant feeling comes to you if you see a small hut surrounded by beautiful shade and ornamental trees. What a comfort does a single shade tree afford a farmer, when after he comes home from his toil in the field he can recline under the same and take $h$ is afternoon nap.

Therefore, plant shade and ornamental trees around your house and you will be repaid for your trouble in many different ways.

Umbrella China-A native of Harris County and now widely known over the state. It is the finest and quickest growing of all shade trees. We have all sizes at the following prices: 3 to 4 feet, 35 cents each; 6 feet and over, 50 cents each, $\$ 5.50$ per dozen. We are the largest growers of Umbrella China trees in Texas, and have over 20,000 this year to offer.

American Elm-Long-limbed, fast growing, is always admired; grows well on any ordinary soil. Price, 6 feet, branched, 50 cents each, $\$ 5.50$ per dozen; 8 to 10 feet, $\$ 1.00$ each.
Ligustrum Japonicum makes a splendid evergreen shade tree; leaves dark green, pointed. 2 to $21 / 2$ inches long; produces large bunches of creamy white flowers, followed in autumn by purple berries. Price of trees, well trimmed, 3 to 4 feet, 50 cents each; 5 to 6 feet, 75 cents each, $\$ 7.50$ per dozen; 6 to 8 feet, extra heavy, $\$ 1.50$ each, $\$ 15.00$ per dozen.

Populus Alba-Silver leafed poplar. Quick growing shade tree; a compact rapid growing tree; very hardy, 5 to 6 feet, 35c each.

Salix, Discolor-Pussy Willow. A quick growing hardy shade tree, very ornamental when in bloom in the early summer. 4 to 5 feet, $50 \mathrm{c}$ each.

Carolina Poplar-A rapid growing native shade tree; is very largely planted as a street and avenue tree, and is very popular. 5 to 6 feet, 50 cents each; 6 to 8 feet, 75 cents each.

Judas Tree or Red Bud-A very long-lived shade tree; very hard wood; large round leaves, making a dense shade. It is not a quick grower. The first tree to bloom in spring; has very pretty red flowers which last a few weeks. Price, 4 to 6 feet, 50 cents each; 8 to 10 feet, $\$ 1.00$.

American Ash-A tree which is particularly well adapted to this latitude; makes quick growth and forms nice tops; leaves are a lively green color. 6 to 8 foot trees, 50 cents each. $\$ 5.50$ per dozen. 
Chinese Elm-Quickest growing Elm tree. Makes a quick shade; does not break. The finest shade tree for street planting. Trees 5 to 6 feet, $\$ 1.00$ each; 7 to 8 feet, $\$ 1.50$ each,

Streculia Platanaefolia (Japan Varnish Tree) - A very hardy and at the same time very beautiful shade tree. It is particularly adapted to this climate, but not very well known. The stem is always straight and smooth and has the same color as the leaves, which are a beautiful light green. The leaves are from 6 to 10 inches across. Tree produces a spreading and dense top, and grows to a very large size. A tree of fancy appearance, but stands as much drought as a hackberry. 4 to 6 feet, 50 cents; 6 to 8 feet, 75 cents; 8 to 10 feet, $\$ 1.00$ each, extra heavy, $\$ 1.50$.

Sycamore-A lofty wide-spreading tree, hand shaped leaves; valuable for its handsome follage and free growth. 5 to 6 feet, 50 cents. 6 to 8 feet, $75 \mathrm{c}$ each.

Weeping Willow-A grand old tree for the cemetery and for the lawn. Should be planted in deep, rich soil where it is constantly moist. 4 to 6 feet, 60 cents each.

\section{Tamarix}

4 to 5 feet, 40 cents each, $\$ 4.00$ per dozen.

Taririfloracans-Large, dark green foliage upright growth; can be grown into a tree.

Canaris Jap. Plumosa-Finest of them all. Upright, curly light green, feathery leaves.

Estivalis-A constant bloomer. Pink blooms, greyish foliage; very attractive.

Indica-Upright; dark green, thick foliage; a late bloomer; flowers come in clusters, light pink color.

Oddeseana-Neat grayish foliage; flowers rose colored; very profuse bloomer; blooms from June to August.

Tamarix Africana-Fine feathery foliage, like that of the Juniper; valuable in sand or soil where most shrubs will not do well; upright growth; small pink flowers on long stems.

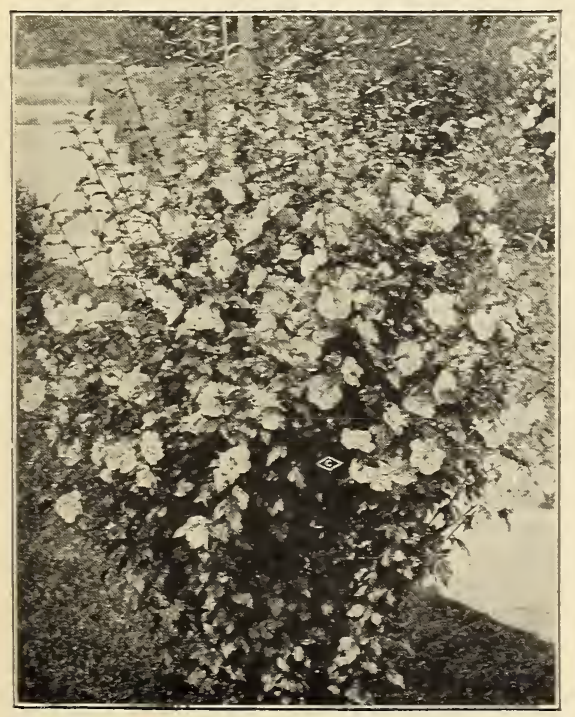

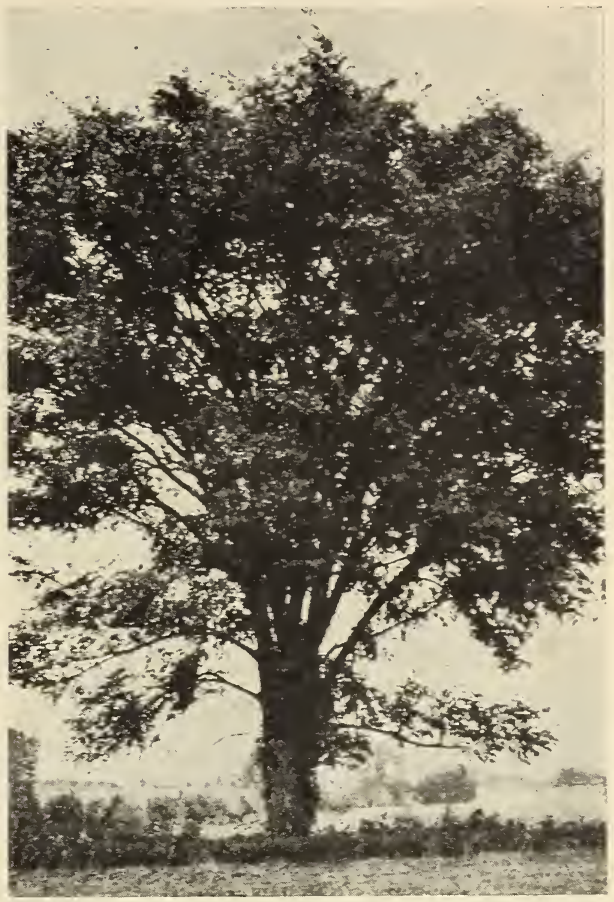

\section{Shrubs}

All the following shrubs have been tested for years and found to be especially adapted to the South. I have a splendid stock of fine plants for this year's trade.

\section{Altheas}

\section{Grafted on hardy stock.}

One of the best hardy flowering shrubs that we know of, and most especially adapted to West Texas, for the reason that it blooms during the entire summer, even when monthly roses and other everblooming flowers are not in bloom. The flowers are not in the least affected by the sun in July and August, but are just as beautiful as they are in the cooler months. Price of strong plants, 2 to 3 feet, 35 cents each, $\$ 3.50$ per dozen.

Beule de Feu-A good double red variety; opens well.

Duchess de Braband-White, red inside; very double.

Lady Stanley-Large double pink.

Tota Alba-Single, pure pearly white; dwarf habit; earliest of all Altheas to blonm and blooms freely. Don't overlook this surt because it is single. It is very desirable.

Althea Rosea-(Seedling.) Mixed, all colors from best seed. Strong plants, 2 to 3 feet, 20 cents each, or $\$ 15.00$ per 100 . The best and finest summer bloomer.

\section{Syringa-Lilacs}

35 cents each, $\$ 3.50$ per dozen.

Purple LMac-A well known favorite.

Syringa Rothomagensis-Red Persian Lilac; very profuse bloomer.

White Lilac-Double. 


\section{Crape Myrtles}

The Crape Myrtle has reached such a high degree of popularity that there is hardly a flower garden without a few of these lovely flowering shrubs. They are lately being used for hedges, which produce the most striking effect, and such a hedge is admired by all who see it. The first flowers appear early in May, and from then until frost the plant is contin. ually a mass of flowers. Price of strong plants, 2 to 3 feet, 35 cents each; 2 years, at 50 cents each, or $\$ 5.50$ per dozen.

Pink-The earliest of all Crape Myrtles to bloom. Tree is of rather a dwarfish habit, but produces more flowers in one season than any of the others.

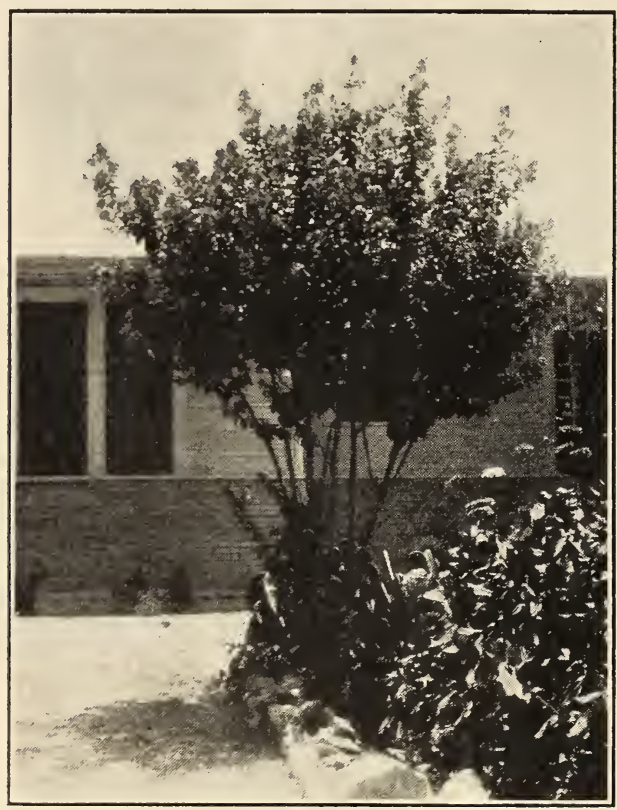

Red Crape Myrtle

Crimson-Grows to a good sized tree, and is almost always in bloom. The flowers are of a very rich crimson color.

Purple-The largest of all; produces very pretty purple flowers in great clusters.

White-Is a very profuse bloomer, but slower grower.

\section{Spirea}

Spirea Van Houttei-A splendid new garden shrub, and one of the most beautiful of all. Immense bloomer with snow white flowers. Extra strong, 35 cents each.

Anthony Waterer-A fine hardy perpetual blooming shrub, particularly desirable for the door yard and lawn, or wherever fine hardy flowering shrubs are wanted. Rich, rosy red flowers in large round clusters; very free bloomer. Price, 50 cents each.

\section{Lonicera (Upright Honey Suckle)}

Alba (White Tartarian Honeysuckle)-Forms a high bush, with creamy white, fragrant flowers. 2 to 3 feet, 35 cents each.

Lonicera Morrowi (Bush Honeysuckle)-A handsome Japanese variuty with white flowers during May, but especially valuable for its bright red fruit during the summer and autumn months. Price, 35 cents each.
Lonicera (Red Bush Honey Suckle)-This upright honeysuckle has pretty fragrant pink flowers, fine for florists; grows in round bush 4 to 5 feet.

Flowering Willow (Chilopsis Linearis)-Native of the dry sections of Western Texas and Mexico. They bloom constantly from May till late fall; grow on any soil and are long-lived. The lace-like followers are about an inch and a half long and are borne in clusters. Color, purple, 4 to 5 feet, 35 cents each; white, 4 to 5 feet, 35 cents each.

Nandina Domestica-Japanese Nandina. Upright growing evergreen shrub with reed-like stems springing from roots. Leaves glossy green when young tinged with red. In winter beautiful bronze tones are assumed. Flowers white on long panicles followed by masses of small bright red berries that are held all winter. Good in group planting or as specimens. Price, $1 / 2 \mathrm{ft}$., pot grown, 50 cents each; $1 \mathrm{ft}$., $\$ 1.00$; 2 ft., $\$ 2.00$.

Philadelphus Grandiflora-(Syringa or Mock Orange)-The Philadelphus is an invaluable shrub. Of vigorous habit, very hardy, with large handsome foliage and beautiful white flowers produced in the greatest profusion in the blooming season. It merits a prominent place in all collections of shrubbery. 2-year-old plants, 35 cents each.

Salvia Greggii-New, hardy, everblooming, red-flowering shrub. A native of West Texas. Extremely hardy, is a great drought resister and has stood a temperature of ten degrees below zero. It flourishes and blooms profusely in hottest and driest weather. It is as near an everblooming plant as we have ever seen. It begins to bloom in early spring. The blossoms literally cover the plant. It requires a killing frost to check its flowering and a light frost in fall does not stop the blooming. The color is an indescribedly lovely shade of red. It is a hard wooded shrub, and adds another good shrub to the already good assortment of the Southwest. Grows 3 to 4 feet high, and is very full and neat in appearance. Field grown plants, 25 cents each, $\$ 2.50$ per dozen.

Vitex Agnus Castus-(Chaste Tree)-A very large, showy shrub with compound leaves composed of five to seven leaflets, dark green above and downy grey green beneath. The flowers are borne profusely during the late summer, in long, dense, terminal racemes. Color Lilac and White, 3 feet, at 50 cents each.

Coral Berry-A hardy shrub, that is very useful for borders, hedges and general land. scape work; has red berries in the autumn, the bush being covered with brilliant red berries. Price, 2 years, 35 cents each; per dozen, $\$ 3.50$.

Pomegranate-Red, flowering double; much used for parks. Blooms all summer, is very hardy. 2 years, 25c each; $\$ 2.50$ per dozen.

Deutzias-Pride of Rochester. Grows strong and upright, 4 to 6 feet high; flowers very double and full. Pure white tinted with blush. Price, 50 cents each; $\$ 5.50$ per dozen.

\section{Plumbago}

Capensis-A well known variety; sky blue flowers. Price, 35 cents. 


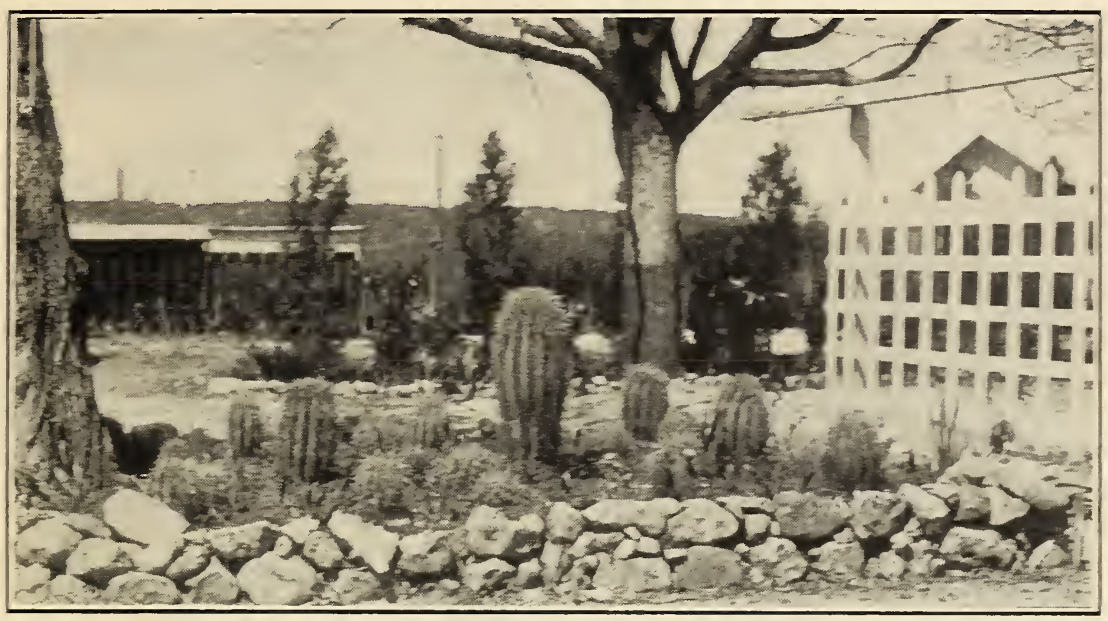

Cactus Beds, Desert Plants in Grea: Demand.

\section{YUCCAS}

Spanish Bayonet-(Fucca Treculeana). The trunk reaches a height of 10 it. Dart steen leaves topped in spring with a great truss of cream white flomers. Plants 2 to 3 fi. high. $\$ 2.00$, balled.

Red Yucca-(Hesperalos Parviflora). Bloom ing size, \$1.50 each. One of the rarest plants in existence. Native of a limited area of Tes Texas and Mexico. Dark green, pliant leares. Flower stalks 5 to $6 \mathrm{ft}$. corered with scapes of brilliant coral red flowers from April till late summer. For beauty and hardiness we can hardly name an equal.

Dasylirion-Plants with leares, ? ft. \$1.50 Each.

Older plants hare a hundred or more leates symmetrically arranges, of a brilliant intense green erery day in the rear. Fine for large urns, rockeries and lawns.

Cactus-10 Texas rarieties, 50c each.

\section{Miscellaneous Shrubs}

Abelia Grandiflora-One of our most beauti ful, popular and satisfactory broad leared erer. greens. The graceful drooping stems and branches are corered with dark glossp leaves which in winter assume a metallic sheen. From the middle of May till frost this plant produces and immense quantity of tubular shaped white Howers, about an inch long which are borte it clusters. We strongly recommend this glant for single specimets, grougs or for bedges. Price, 2-vear plants from open field, is cents Each; 3-Tear, \$1.00 Each.

Buddleia Lindleyana (Summer Lilac)-One of the most desirable summer flowering shrubs. Beginning to bloom in Julp, it contintes until cut br setere frost. The flowers are of a pleas. ing shade of riole: maure, and are borme in dense cylindrical spikes. It succeeds erery. where, and flowers freely the first season planted. Price, jo cents eEch.

Ligustrum Lucidum-Prapid groming erer. green with thick glossy leates. 2 to 3 feet. $\$ 1.00$ each; 3 to 4 feet. $\$ 1.50$ each.

Aster-Grandiflora Texanum. Improred na. tive aster, profuse mass of bluish flomers; blooms in the fall; groms 4 ft tall Clumps. Price. 35 cents each.

Elderberry-35 cents. Trusses of white flom ers in summer. Desirable.
Evergreen Shrub-Leucophrllum Texanum. Etergreen, ashen colored foliage. Pale lilac flowers throughout summer. Escellent for coztrast effects. Price. $\$ 1.00$ each.

Eupatorium-i5 cents. Shrub ? to 3 feet with wonderful fragrant white flowers in fall. It is corered with butterflies on fair dars.

Flowering Almond-Double pink; a shomer of color in early spring; rery hardy. Price, 75 cents each.

Weigellia-Tonderful, important group of shrubs for specimens and desirable for groups and masses. In spring Weigellias are aglow with a wealth of flowers. Ara Pathbe and Rosea. 2 rears, 50 cents.

Mallow Marvels-Improred, hardy hibiscus Large flowers. White, pint, crimscn and scar let. 2 jears, 50 cents.

Xmas Trees- We hare nice, round mountain cedar trees especially suited for Xmas trees, at following prices: $3 \mathrm{fth} 50$ cents each; $4 \mathrm{ft}$. 750 each; 5 ft., $\$ 1.00$ each.

\section{MISCELLANEOUS PLANTS}

A general assortment of plants for all pur. poses. Decoratire, Bedoing or Greenhouse StOCE.

Asparagus Plumosa-TLe most raluable ere:green trailing plants of the house and conserta. tor: erer groduced. Their beautiful sprars of lorely. feathery foliage can be cut freely for bouquets. Price, 35 cents each

Asparagus Sprengeri-The fronds are long and wirs, and for flat bouquets nothing equals it, for. while tleecy in appearance. in reality it is rery stiff and forms an elegant sugport for Howers. Price. 35 cents each.

Alternantheras-1j cents each, $\$ 1.50$ pe: dozen.

Rubber Trees. Elastica-The well-knomn rubber plant t-inch pot, 10 inches high. 75 cents each; 6-inch pot, 20 to 24 inches high, $\$ 1.50$ each.

Acalphas-Acalpha tricolor. Pich and beat. tiful. Mottled and blotched with crimson and scarlet on green background. Foliage extra large and maintains its marbings regardless of summer Leat. Price, 15 cents each, \$1.60 pel ¿ozez. 
Ageratums-Blue perfection, as necessary to your beding stock as Coleus or Geraniums. Dwarf in growth, true blue and always in bloom. Price, 10 cents each, $\$ 1.00$ per dozen.

Banana Orinoca-Price, $\$ 1.00$ each.

Mint-English Mint. $\$ 1.00$ per dozen.

Poinsettia Pulcherrima-Price: 1 foot, 50 cents each; 2 feet, 75 cents each. This is the plant which produces the large clusters of red leaves or flowers which are seen in all the flower stores at Christmas. We offer fine plants.

Pinks-Hardy sorts. $\$ 1.00$ per dozen.

Petunias-Best double varieties. 15 cents each, $\$ 1.50$ per dozen.

Hyacinths-For the Garden or Pot Culture. Any color, white, pink, yellow, blue and red. 15 cents each, $\$ 1.25$ per dozen.
Parlor Ivy-Price, 50 cents each. A lovely climber for the house or window, grows very quickly and makes an abundance of pretty green foliage.

Salvia-Price, $\$ 1.00$ per dozen.

Fireball-Grand New Salvia. Retains its brightness and profusion of bloom as well in July and August as in September and October. Its height is about 18 to 24 inches.

Verbenas- $\$ 1.00$ per dozen. All mammoth varieties.

Vinca Variegated-(Variegated leaves). Price, 25 cents each, $\$ 2.50$ per dozen. An elegant, low growing, trailing vine; bright, glossy green leaves, widely bordered with creamy white; extra nice for pots, vases, baskets, window boxes and rockeries; good everywhere; always wanted.

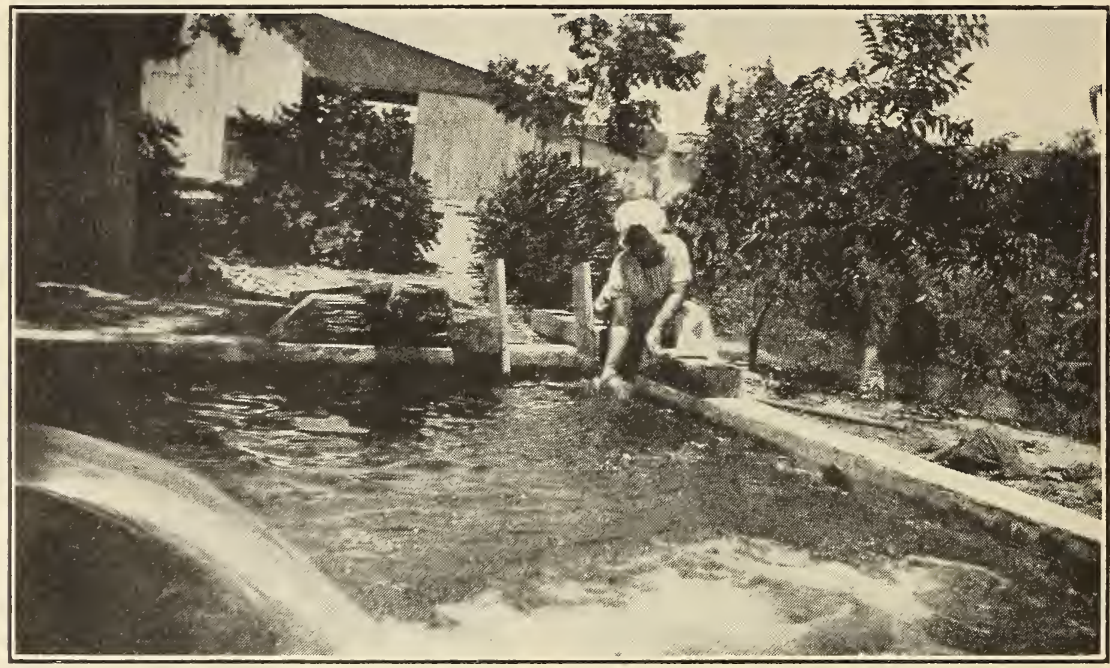

Four Wells Like This Make the Trees and Flowers Thrive.

\section{Broad Leaved Evergreens and Balled Evergreens}

Amoor River Privets (South)-Of similar form and habit to the California type, not so shiney, but hardier, leaves small, round, very dense. 2 to 3 feet, 25 cents each; $\$ 2.50$ per dozen, $\$ 15.00$ per $100 ; 1$ year, $\$ 8.00$ per 100 .

Buxus Arborea (or English tree box)-Succeeds almost every where. It is of rather slow growth, compared with other evergreens. Remarkable for its longevity, and finally gets to be 10 or 12 feet high. The Buxus makes the finest evergreen hedge. Strong, two-year-old bushes, 50 cents each, $\$ 5.00$ per dozen.

California Privet-Splendid for specimens. screens, hedges. 2 to 3 feet, 10 cents. For hedging, $\$ 5.00$ per $100 ; \$ 40.00$ per 1,000 . Two years, extra heavy, $\$ 10.00$ per 100 .

Cape Jasmine-Flowers large, white, frag. rant; foliage rich, glossy. Price, large plants, 50 cents each; $\$ 4.00$ per dozen.

Cotoneaster (Panosa)-White flowers, followed by many scarlet berries in winter; leaves ashy color on under sides, giving plant a grayish color effect; very graceful habit; medium size; very attractive. 18 to 24 inch, $\$ 1.50$ each; $\$ 15.00$ per dozen; 2 to 3 feet, $\$ 2.50$ each; $\$ 25.00$ per dozen.
Elaeagnus (Simonsi)-Erect shrub, medium size, silvery branches, leaves silvery beneath, giving a very pleasing and attractive color effect; hardy. 18 to 24 inch, $\$ 2.00$ each; $\$ 20.00$ per dozen; 2 to 3 feet, $\$ 3.00$ each; $\$ 30.00$ per dozen.

Euonymus (Globe Shaped)-Grows very compact, globe shape, small leaves; upright habit, both green and silver variegated; handsome for formal effect. 12 to 18 inch, $\$ 1.25$ each; $\$ 12.50$ per dozen; 18 to 24 inch, $\$ 1.50$ each; $\$ 15.00$ per dozen.

Euonymus Japonica--One of the fastest growing evergreen shrubs, suitable for either hedge or single specimen; can be greatly improved by cutting back to induce bushy form. No evergreen has such a bright dark green color in winter as this. For quick results this excels. Fine 2-year plants, 25 cents each; $\$ 2.50$ per dozen; 2 feet, strong, 50 cents each; extra large, 75 cents each.

Feijoa-Silvery green leaves, spreading habit; flowers waxy petals, white beneath, purpling crimson on upper side; fruit delicious, mingling flavor of pineapple, raspberry and banana; im- 
parts a rery pleasing fragrance in a room; rery hardy. 2 year, 18 to 21 inch, $\$ 1.50$ each; $\$ 15.00$ per dozen; 3 rear, 2 to 3 feet, $\$ 2.00$ each; $\$ 20.00$ per dozen.

Hypericum (Gold Flower)-Low spreading habit; hards. 2 rear, 2 feet, $\$ 1.25$ each; $\$ 12.50$ per dozen.

Ibota-Spreading and tall, the hardiest priret; color greyish green; fruit black. 2 to 3 feet, 20 cents each; $\$ 2.00$ per dozen; $\$ 15.00$ per 100.

Japan Medler Loquat-Trees of medium height, with long, glossy leares, which are evergreen; flowers white in spikes, and produced in winter. Fruit of the size of a wild goose plum, round or oblong, bright yellow, and produced in clusters; sub-acid and refreshing: maturity from end of February to April. 2-year field plants, 75 cents each; 3 -year, $\$ 1.50$ each.

Lavender (English)-Tery small shrub with grat downy foliage; rery aromatic; blue flowers; hardy. 12 to 18 inch, $\$ 1.00$ each; $\$ 10.00$ per dozen; 18 to 24 inch, $\$ 1.50$ each; $\$ 15.00$ per dozen.

Loquat-Japanese erergreen plum; handsome, large, rough leares; sturdy gromth; vig. orous habits. 2 rear, 18 to 24 inch, $\$ 1.50$ each; $\$ 15.00$ per dozen.

Magnolia Grandiflora-Its large, shining green foliage, accompanied in summer with large, fragrant, milky-white flowers, places it pre-eminently above all ornamental trees. This. as well as all other erergreens, should be handled and planted very carefully, as thes are extremely sensitive to injury from drying. Their roots should never be allomed to get dry when out of the ground. In planting, the soil should be pressed firmly about the roots. Two feet, 75 cents; 3 feet, $\$ 1.00$ each; 4 to 5 feet, $\$ 1.75$ each.

Photinia-Handsome strong growing shrub; leares large, deeply serragated, glossy green with reddish hue when small; upright habit; rery striking; hards. 2 to 3 feet, $\$ 2.00$ each; $\$ 20.00$ per dozen.

Pittosporum Tobira-One of the finest erer. green shrubs. Well adapted for trimming. Grows round and compact. Pot gromn, 75 cents each; field grown, balled, $\$ 1.50$ each.

Rosemary-Evergreen with greyish green foliage highly perfumed, used for medicinal purposes. 2 rears, 50 cents each; per dozen, $\$ 5.50$.

Yellow Jasmine-Flowers bright yellow in clusters; strong grower; rery fine for low massing. 2 year, 18 to 21 inch, $\$ 1.00$ each; $\$ 10.00$ per dozen.

Yucca Filamentosa-Evergreen. This plant is an object of beauty the year round. The leares are 2 feet long, bristling out of all angles, with sharp points; flower stalks stout. Four feet high, with 100 to 200 bell-shaped creamy white blossoms hanging from branch. ing arms. Perfectly bardy and lives to a great age. Two years old, 25 cents; $\$ 2.50$ per dozen.

\section{Cone-Bearing Evergreens}

Bonita-A new Arbor Vitae of the greatest merit, a chance seedling originated in our nursery. It is of a perfect round growth. dwarf and as round as a ball; has the beau. tiful green color of the Arbor Vitae, but the leaves are much thinner. This is the only Arbor Vitae to plant in the cemetery, as it has the round, compact form, and never gets over three feet high. It is a seedling among 3,000 Compacta Arbor Vitaes; is better than the Biota Nana and more dwarf than any ret in existence. We have some nice, round plants 12 to 18 inches, $\$ 2.00 ; 2$ feet, $\$ 3.00$.

Golden Arbor Vitae-This is the handsomest and most compact of the Arbor Vitaes. Green. with a beautiful golden tint. True grafted trees. $2 \mathrm{ft}$., $\$ 1.00$ each; $4 \mathrm{ft} ., \$ 2.50$ each.

True Berkmans (Biota Aurea Nana) - A new Golden Arbor Vitae of a dwarf and compact habit; a perfect gem for small gardens or cem. etery lots; will not grow higher than 6 to 8 feet. $2 \mathrm{ft} ., \$ 1.00$ each; $4 \mathrm{ft} ., \$ 2.50$ each.

Chinese Arbor Vitae-Dark green, vigorous, hardy, desirable. Two to 3 feet, 75 cents each; 4 to 5 feet, $\$ 1.00$ each.

Golden Pyramidalis Arbor Vitae-Like the Golden, but grows tall and slender. A rerr ornamental sort. Do not confuse this with Cupresses Pyramidalis. 3 to 4 feet, $\$ 1.50$ each.

Compacta Arbor Vitae-A seedling, compact growing Arbor Vitae, of a lively dark green color, and of globular shape. 2 to 3 feet, $\$ 1.50$ each.

Cupressus Pyramidalis-This is a beautiful tall, columnar evergreen. Does Tell in Texas; a little tender in far North. Pot gromn, sure to live. One foot, $\$ 1.00 ; 2$ feet, $\$ 2.00 ; 3$ feet, $\$ 3.00$.

Rosedale Arbor Vitae-Very compact growth. with sugar loaf form of the Golden Arbor Vitae. but with fine, cedar-like foliage of a bluish cast. Makes a beautiful ornament, perfectl: hardy and rigorous growth; the most beautiful of all Arbor Vitaes. One to 2 feet, $\$ 1.00$ each 3 feet, $\$ 2.50$ each.

Seedling Arbor Vitae-1 to 5 feet, 75 cents each; $\$ 8.00$ per dozen.

Juniper Sabina-"Savin Juniper." A semi spreading shrub of great beauty. Evergreen bluish or gray-green. Balled, $\$ 1.00$ each.

\section{Hardy Out-door Palms}

Washingtonia (Prichardia Filifera) - The hardiest of the Washingtonia trpe, quick grow. er, more erect. Large plants, weight 50 to 100 pounds. 3 feet, $\$ 2.00$ each; 4 feet, $\$ 3.00$ each.
Sabal Palmetto-The famed cabbage Palmet to. This forms a tall tree with a large head of fan leares. This tree can be grown all orer the South, and is rers hards here. 2 to 3 feet, $\$ 2.00$ each; 4 to 5 feet, $\$ 4.00$ each. 


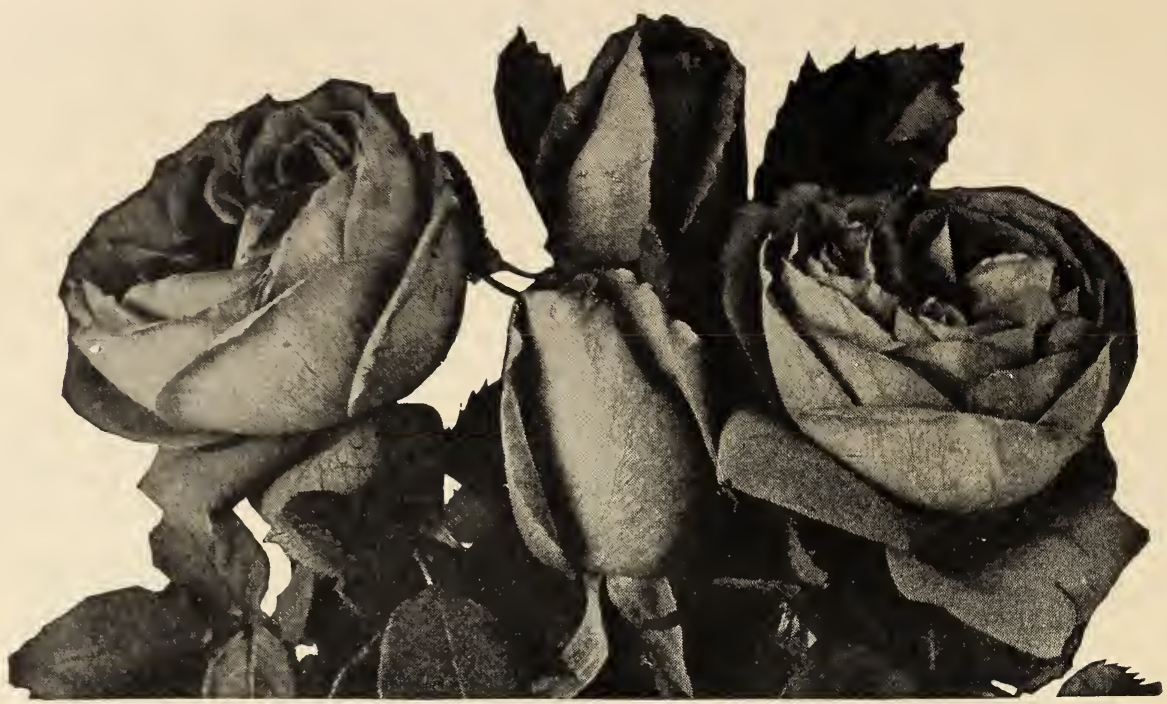

Roses

Strong field grown, 1 year old, 35 cents each; $\$ 4.00$ per dozen, except where otherwise noted;

2 year old, extra strong, 50 cents each; $\$ 5.50$ per dozen;

3 year old, extra strong, 75 cents each; $\$ 8.00$ per dozen.

Of all the flowers which man has taken into care, the rose has reached the highest degree of popularity. It is the queen of flowers, the flowers of poets, and will always be the dearest of flowers to the lover of the beautiful.

While wild roses are met with in almost every country, the cultivation of the rose began probably at the same time when the cultivation of man began, and with the cultivation of man that the roses has kept pace, being now at the same height of development as is humanity.

of the many thousands of varieties which have for centuries been introduced by the hy. bridizers, those of each succeeding century show a marked improvement over those of the foregoing. Of the roses which were con. sidered the best only a century ago, very few are grown today.

Many hundreds of different varieties have been tried on our grounds, and of all only such are described in the following list, which in our judgment, are the very best for outdoor planting.

Fortunately, we live in a climate where even the tenderest roses stand the winter without cover, and any of the roses in this catalogue may be planted outdoors.

Plant your roses in an open place. Never try to grow roses in the shade of trees. The plants you receive from us are grown by the latest methods of cultivation which we practice together with a means of accumulating power and strength in the young plants, and which is just the opposite from forcing roses in greenhouses for bloom. Do not set out your roses the way you get them, but trim off at least one-half of the wood. Slow growing sorts should be trimmed more severely than the quick growing varieties. We are one of the largest rose growers in Texas, and have this year 40,000 extra strong plants to offer.

\section{Crimson and Red}

Gruss an Aachen-Unusually large, compactly double, fragrant flowers in full clusters; a unique and very pretty combination of pink, red and orange.

American Beauty-Hardy rose of largest size, having the everblooming qualities of the Tea Rose, with the delicious odor of the Damask or Moss Rose. In color it is brilliant red, shading to a rich carmine crimson. The flowers are borne on long, stiff stems, hence a splendid rose for cutting. 75 cents each.

Baby Rambler (Mme. Levasseur)-This rose is so well known as hardly to need a word of description. It is a dwarf form of Crimson Rambler, which produces flowers absolutely continuously. Invaluable either for pots or for outside bedding.

Balduin-A new hybrid Tea rose. About the best crimson outdoor bedding rose we now have. It is very strong growing and healthy, and produces very large and double roses of a glowing carmine color, which are as sweet as a June rose.

Crimson Queen-A beautiful crimson hybrid Tea of the Hadley type, but different in tone; a fine grower with broad, beautiful foliage.

Crusader (A Wonderful Crimson)-A big strong-growing variety, robust and rugged in every characteristic. The growth is heavy and the flower stems are strong and heavy, producing very little blind wood. It is free-growing and free-flowering, and the blooms are truly characteristic of the variety-big and double, and, in color, a rich, velvety crimson. These large heavily petaled blooms open perfectly and are amply supported by the strong-necked heavy flower growths.

Etoile de France (Hybrid Tea)-The gold medal rose of France, and claimed by the raiser, J. Pernet Ducher, to be the finest rose 
he has ever sent out. A very strong, vigorous grower, with handsome green-bronze foliage and exceedingly free flowering. The flowers are very large and borne on long, stiff stems. Color, a clear red crimson velvet. Very frag. rant and keeps well. Without any exaggera. tion, we may assert that Etoile de France will be appreciated by all lovers of the queen of flowers.

Francis Scott Key-"The rose of every garden of every American Home. Named in honor of the writer of the Star Spangled Bannerthe new American rose, Francis Scott Key." Dazzling crimson globular rose of gigantic size. The rose is deliciously perfumed, strong, vigorous, free branching with large and handsome foliage.

General McArthur-A grand, new, everblooming crimson scarlet rose. In all the rose family we know of nothing that can compare with this in dazzling color, fragrance of flower and profusion of bloom. Is as fragant as a rose can be, has good sized flowers, blooms continuously the whole season through, and gives fine stems for cutting. It makes a strong. stately plant that may be depended upon for strong flower shoots.

Gruss an Teplitz-We unhesitatingly say that for bedding no rose we offer will compare with Gruss an Teplitz. It is a perfect sheet of rich crimson all summer. When we say that we know of no rose that has such bright colors in it as this variety, we are stating facts. The richest velvety crimson overlaid with the brightest penetrating scarlet.

Hadley-Magnificent Rich Velvety Crimson In the Hadley we have a Rose that possesses a rich and lasting crimson color, coupled with vigor of growth, robust constitution, and free blooming habit. It will be welcomed alike by the grower who forces Roses under glass for cut flowers and the one who plants outdoors for summer flowers. It is a development of a strain of red Roses, including Liberty, General McArthur and Richmond. The color is magnificent, rich velvety-crimson, retaining its brilliancy throughout the season. The fragrance is delightful and refreshing. The flowers are borne on long stems and keep in good condition a long time when cut. The growth is splendid, sturdy and healthy, the foliage large and abundant.

Ideal-Color a rich garnet red, flowers are semi-double, comes in great heads of thirty or more, and is one of the best roses for out-door culture.

Larent Carle-A beautiful Rose, with extra large, handsomely formed, rich velvety carmine buds and flowers. It is a phenomenally strong and robust grower, hardy in every locality and continually in bloom. Every lover of Roses should have this variety.

Mad. Jules Groletz (Red Kaiserin Augusta) -This magnificent Rose is exceedingly free blooming, with very large, finely formed flow. ers. The color is a distinct and charming shade of cherry-red. The fine form and attractive shape of the flowers makes them excellent for cutting. It is a remarkably strong, healthy growing variety, and is as hardy as the Hybrid Perpetuals.

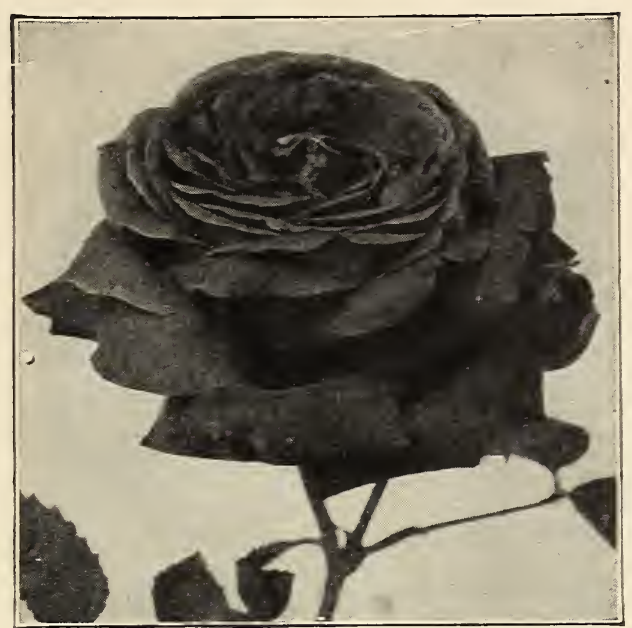

Marie de la Salle-Deep, brilliant cerise; reverse of petals shaded carmine; long shapely buds with large petals opening to full bloom of splendid form. A free growing and continuous flowering bedder.

Mrs. Chas. Russell-Large globular, well formed flowers; very double; of a rosy carmine, with rosy scarlet center. It is of strong branching habit with splendid foliage and very free flowering; one of the very popular cut flower varieties and equally good for the gar. den.

Meteor-A very velvety red everbloomer of the deepest glowing crimson, as fine as a hybrid. Flower very double and petals slightly recurving. A beautiful open rose.

Orleans-A Baby Rose, with charming and dainty clusters of deep cerise flowers with a pure white center. Always in bloom; looks like a large bouquet.

Red Letter Day-An exceedingly beautiful rose of infinite grace and charm. Its velvety, brilliant, scarlet crimson buds and fully opened flowers never fade. Awarded highest medals.

Red Radiance-Same rank grower as $\mathrm{Ra}$. diance, bright red color flowers, double, borne on long stiff stems; one of the finest for cut flowers.

Rhea Reid-One of the Very Best Red Bedding Roses. Rhea Reid is as fragrant as a Rose can be; has good sized flowers and blooms continuously. The bud, when first opening, is the brightest crimson-scarlet and the flower retains this perfect coloring until it drops its petals. Blooms continuously the whole season through and gives fine stems for cutting. Its habit of growth is remarkably good making strong, shapely plants that may be depended on for large flower shoots. A great favorite.

Royal Red-A very distinct red Rose of enormous size and magnificent growth. In the bud and half open stage the coloring is magnificent, scarlet red with almost black shading. The fully expanded flower is of great size, but lighter in color. The flowers are very full, sweetly scented, with fine foliage, powerful stems, and at its best during summer weather. The large full flowers are produced in the greatest profusion. 


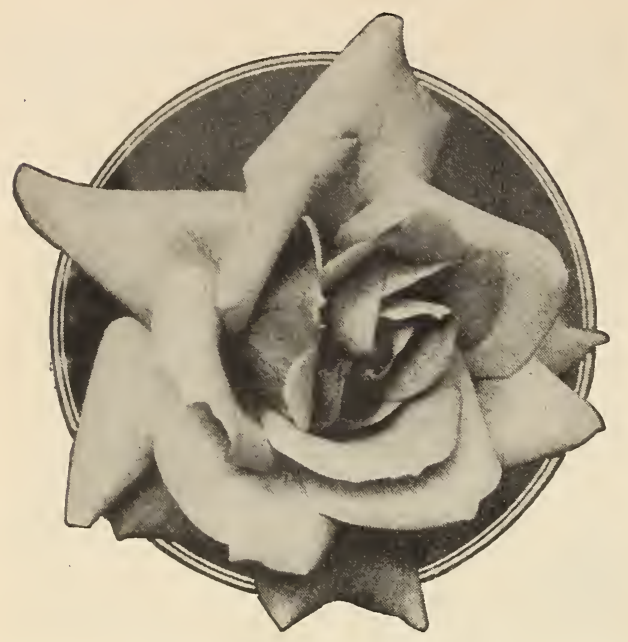

Sensation-As large and more brilliant than Premier. Well supplied with a heavy, luxuriant foliage. The flowers are fine any season of the year. The color is an entrancing shade of red. The bud long pointed and strong, with ample foliage. A good keeper and shipper.

Templar-A comparatively new Rose, of bright velvety crimson. The flowers are quite free with petals of wonderful depth and substance; with its fine branching habit and ideal growth it makes a fine bush Rose.

Miss C. E. Van Rossen-Flower well formed, velvety red; fragrant. Vigorous grower, bushy.

Le Ponceau-Garnet or mahogany red, the darkest of the Polyanthas; vigorous growth, flowering in corymbs.

La Fayette-An epoch-making, decided break from the type. The dwarf, bushy growth, clustered flower heads and continuous blooming, are conventional; but its individual flowers are 3 inches wide, semi-double and prettily ruffled, strung together in great branching sprays of as many as forty. Brilliant cherry-crimson color.

Prince de Arenberg-To those who prefer a rose with full color we can recommend none more highly than this gorgeous crimson scarlet rose. It is hardy in practically all localities and as an outdoor garden rose it has no superior.

Madame Eugene Marlitt-One of the greatest garden roses, wonderfully strong growing, making a sturdy bush about four feet high, heavy leathery foliage like June rose; large, full double crimson flowers of extraordinary beauty and exquisite fragrance.

Mabel Drew-The color is a deep cream in the young state, to intense canary yellow in the center as the flower develops.

\section{Pink}

Antoine Rivoire-A grand fancy bedding rose, very large, very full, perfect in form. Color flesh tints with orange center and carmine edge.

Bridesmaid-The pink sport of Catherine Mermet. It is a stronger grower than its parent; has handsome foliage and the flowers are a much livelier pink. The most popular pink rose ever introduced.

Burbank-Raised by Mr. Luther Burbank of California, known the world over as the "Wiz- ard of Horticulture." The color is cherry crimson. It is, in other words, the very deepest and brightest pink rose in cultivation. One of the freest bloomers and perfectly hardy.

City of Little Rock-A surprisingly beautiful novelty now being introduced for the first time. It is distinct, and beautiful in color, a bright rosy-pink or rose-shaded with hydrangea-pink. The buds which open perfectly are long and of ideal form. The growth is vigorous and the flowers are produced profusely. Its pronounced fragrance will attract all Rose lovers.

Catherine Mermet-A fine pink rose; a good grower and bloomer; one of the best pink roses for outdoor culture.

Champion of the World-A perpetual bloom. er, summer and winter. The flowers, which are produced in the greatest profusion, are perfectly double and of perfect shape. They are of a deep rosy pink and delightfully fragrant.

Columbia-Too well known to need description; glowing pink, deepening as it opens; a marvel of freedom in growth and bloom, with long stems, nearly thornless, quite fragrant, lovely in the bud state, and handsome in the full open flower which turns to deep rose. Own roots, strong plants.

Commonwealth-This rose has large, long, pointed buds, and large open double flowers, borne singly on medium strong stems. The color is an even deep pink, what would be called a solid color, that is, without much shading. Ample foliage with few thorns. A vigorous upright grower and delightfully fragrant.

Frank W. Dunlop-Large double rose, like Premier in shape and color; fine cut flower variety. Large foliage, few thorns.

Hermosa-Popular for many years; cupshaped, finely formed and full flowers of soft, deep pink; ever-blooming, beautiful and hardy.

Jonkherr J. L. Mock-Although introduced only four years ago, this beautiful rose quickly found its place amung our best bedding varieties. The flowers, which are produced in the greatest freedom on long, stiff stems, are of large size and perfect in form, of a deep imperial pink, the outside of the petals silvery rose white; highly perfumed.

Killarney-No rose has attracted so much attention as Killarney. The color is brilliant sparkling pink. The flowers are extra large and full, with broad, thick petals and delightful tea fragrance.

Lady Ashtown-Tender rose shading to yellow at base of petals with silvery pink reflex.

Lady Ursula-Color a most beautiful shade of flesh-pink, of great substance and good form; petals large, circular and delicately perfumed. A grand grower, producing its round, full blooms in wonderful profusion.

Madame Segond Weber--Rosy salmon or flesh pink.

Wm. R. Smith-As a summer bedder this variety ranks above all others; produces immense quantities of fine flowers of creamy white with pink shading; strongest growing of all the summer bedders, making a fine branching bush in one year's time. Has fine, firm, glossy foliage; long flowering stems. 
La France-Perhaps no rose is more wide1. known or more highly valued for a garden rose than La France. It is a hybrid Tea of very beautiful form and color; an early and constant bloomer, producing a wonderful profusion of buds and flowers all through the growing season. It is exceedingly sweet and handsome, and altogether one of the loreliest and most desirable roses one can plant. The color is a delicate shade of peach blossom, changing to amber rose, elegantl tinged with crimson.

Los Angeles - Wt rould not consider any collection of roses complete without Los Angeles, one of the finest roses ever intro. duced. The growth is very rigorous and produces a continuous succession of long. stemmed flowers of a luminous flame pink, toned with coral and shaded with translucent gold at the base of the petals. Buds are long and pointed and expand into a flower of form and ever-increasing wealth of color is maintained from the incipient bud until the last petal drops.

Mme. Caroline Testout-A magnificent hr. brid Tea, of the rery lorliest shade of pink.

Maman Cochet-A magnificent pink rose of the Mermet type. The grandest of outdoor bedders in pink, making an enormous growth in one season. Color rery bright, rose with shading of rellow in center.

Malmaison-This is certainly one of the choicest, and as a rose for general cultiration is unsurpassed. The color is a beautiful rich. creamy flesh, with a rose center; flowers rery large, perfectly double and deliciously fragrant: a strictly first class rose in erery respect.

Paul Neyron-Deep pink, rert large and extra fine rose, and rery free bloomer. A rose without thorns.

Premier-A magnificent rose of large size, rerr deep rose color. The broad roll of the outer petals creating most interesting lights and shadows. It is practically thornless. 75 cents each.

Souv. De President Carnot-Rosy flesh. shaded white; large, fine form; semi-double.

Radiance-A grand freegrowing, big habited rose, with long stems and globular blooms of intense rose pink color; rert fragrant. 1 fine summer variety and the finest of all the out. door pink beding roses. Alrays in heary demand.

\section{Yellow}

Alexander Hill Gray-The respect of all rose lovers warrants the issuing of a champion rose. and a tea at that, to pay due homage to one of the Forid's greatest tea rose growers. It is wonderfully floriferous, every shoot being cromned with a flower bud, which derelops into a bloom of rery large size, great substance and perfect formation, with high pointed center from which the petals gracefully reflex. The best and largest pure rellow tea rose yet intro. duced. Its color is a solid deep throughout. Marechal-Neil like lemon-yellow; strongl! tea scented.

Amelia Gude-A unique and charming yellow rose; color of Sunburst, with deeper shadings

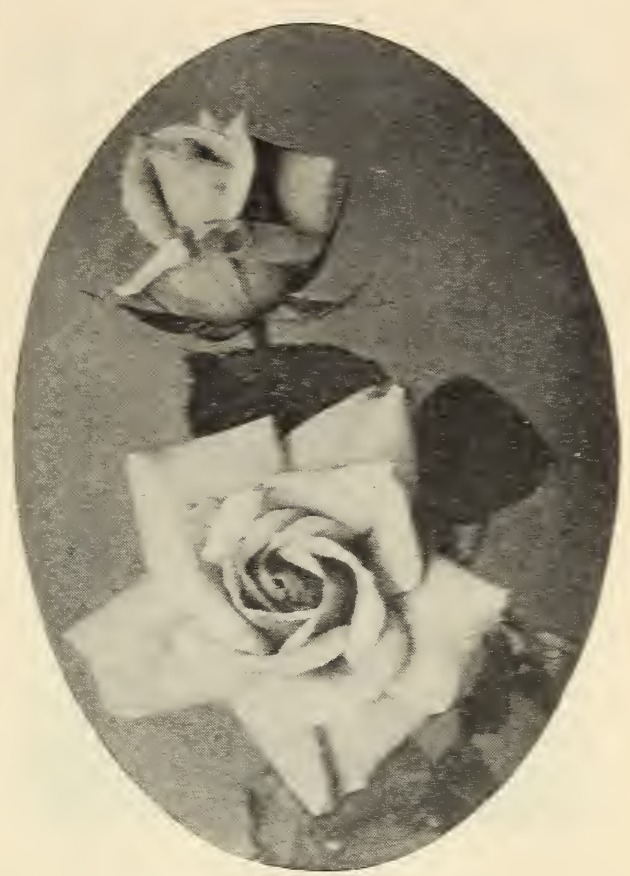

on the reverse; a true fancy rellow. The blooms hare an indiridual beauty not alkays found in the big buds of the modern varieties. It is ideal for table decorations, corsage bouquets, baskets. It heeps well.

Aaron Ward-A color that catches the eye at once, copperage, golden orange in the full flower; fine pointed buds; rert popular.

Baby Doll or Tip Top-Brilliant golden rellow tipped with clear, bright cerise, lorely miniature "Sweetheart" buds and blooms of perfect form and finish, borne in erect panicles of single, deep, glossy green foliage, narrop, long and sharply pointed; in the Brunner class for corsage and dainty floral work.

Dudley Cross-Light yellow rose, good bloomer. Best gromer of the light jellow roses; long pointed buds.

Souvenir de Pierre Notting-This is a beau. tiful rose, seedling of Marechal Niel and Maman Cochet, with beautiful closelp.set foliage and strong, sturdy habit of growth. The bloom is rert large, perfectly full, of elegant form, has a beautiful long bud. The colors are rery bright, distinct and clear, and hare no unpleasant tones-orange rellow, bordered in carmine rose.

Etoile de Lyon-Many new rarieties of rel. low roses hare been introduced since this thas a norelty, but none ccmbine more good quali. ties than this good old sulphur-yellow rose. Buds are of beautiful shape and flower is rert full.

Golden Ophelia-Similar in habit of gromth and freedom to Ophelia but with a pretty gol. den rellow suffision.

Mrs. Arthur Waddell-A strong, rampan: grower; buds long and pointed; rose scarlet. opening coppery salmon; large and semi-double. but a monderful keeper. One of the showiest roses extant; a splendid forcer. 


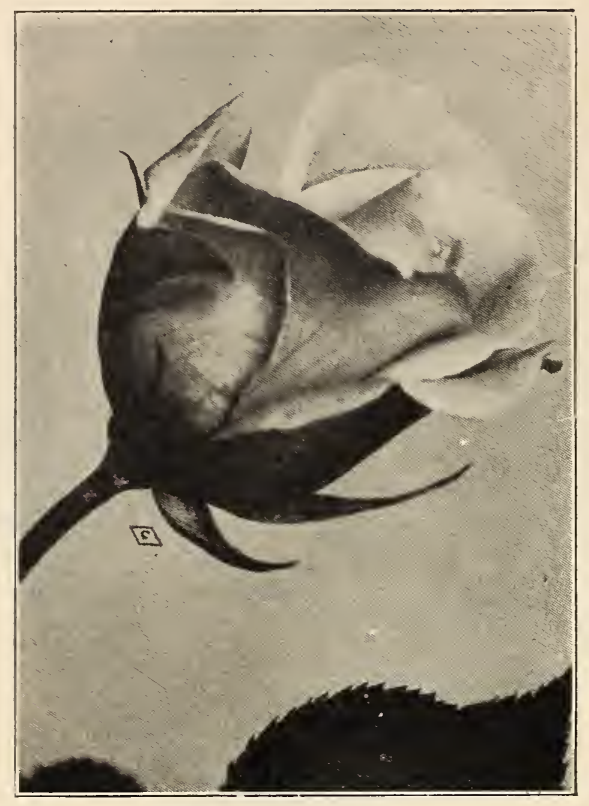

Francisca Krueger-A strikingly distinct anò handsome rose. One of the very best for open culture. The flowers are deeply shaded copper. yellow in color and are of large size. Always in bloom.

Helene Gambrier-This lovely yellow hybrid Tea everblooming rose will fill a long-felt want from the fact that everybody has been looking and longing for a good yellow rose that com. bines vigorous hardiness with rich color and free blooming qualities. This Helene Gambrier does. Flowers are of a delightful shade of deep, rich yellow.

Luxemburg-Grand golden yellow rose, H. P. strong grower, heavy foliage; a good rose.

Mme. Cecile Brunner-Synonyms: Mignon and Sweetheart. The tiny pink Polyantha rose, extremely useful in the cut flowers trade, where it has acquired new popularity the past two years; forces nicely in winter time.

Mme. Butterfly-Sport of Ophelia. Of freer growth than its parent. All the color tones of Ophelia are intensified, making it a harmony of bright pink, apricot and gold. It averages more petals to the bloom. It produces more blooms to the plant, because it makes more branches. every one carrying a bud, consequently requires fewer plants to fill the bench. The tight buds are a lovely shade of Indian red, yellow at base. They are unique for corsage and for low table decorations. The opening flowers are perfect in form and texture, clear and brilliant in color and of delicious perfume.

Lady Hillington-A very popular yellow forc. ing variety, already planted in considerable quantity in this country. It is of very quick, free growth, with pretty narrow foliage, and is one of the freest in the tea section in the con. tinuous production of flowers. The buds are slender and graceful, a deep shade of yellow which does not easily fade. Everybody can grow this pretty yellow rose and have it in quantity.

Ophelia-Is grown by every wide-awake florist. The queen of fancy roses; orange salmon. No forcing variety ever attained such wide popularity so promptly and it tops the list of profit. It has the handsomest foliage in the family, ample, large and of wonderful texture; noted for its splendid stems. It is the most fragrant of forcing varieties, with the full June-rose fragrance. Ophelia stands charged with pushing Killarney off the stage. There ought to be room for both.

Sunburst-This big yellow rose is in a class by itself. It has proven a valuable summer variety and has made many friends. It is also a fine cut flower variety throughout summer and is a marvelous keeper, the color being beautiful, whether it comes light or deep orange. Being an all-the-year round rose makes it profitable.

"Climbing Columbia"-A hardy everblooming pink climbing rose, the latest and most beautiful rose of recent introduction. This hose is a sport of the well-known Hybrid Tea Rose, "Columbia," and has all the desirable features of its parents, with a remarkable climbing tendency, growing 10 to 15 feet in a single season. Foliage deep glossy green, immune from disease and insects. Hardy in any location. Blooming with the greatest freedom the entire season. Equally as well in the far South as in the North. Buds and blooms of immense size, often measuring six inches in diameter, and perfect formation, borne single on long shoots, thus making it an ideal one for cutting. Buds long and pointed, same as "Columbia," opening full and double. Petals large. Color, clear imperial pink with paler edges, beautifully dark veined; delightfully fragrant. This rose has so many good qualities that we predict it will soon be one of the leaders in its class.

Paul's Scarlet Climber-Winner of gold medal as best new climbing rose at National Rose Society's Exhibition. Flowers are scarlet, shaded crimson; large, semi-double. Corresponds with Cl. Am. Beauty, Dr. Van Fleet, etc., as to size, shape and habit. Blooms very long, holding in flower after many June bloomers have dropped their petals; a wonderful rose for trellis or pergola use.

\section{White}

Catherine Zeimet (White Baby Rambler) This is surely a beauty. It grows to a height of 15 to 20 inches, and produces double pure white flowers in wonderful abundance. It has a fragrance similar to hyacinths. Of free, compact growth and very attractive, a sheet of white and always in bloom. Extra strong. 50 cents each.

White Killarney-With many growers used in preference to the original White Killarney, as it has many more petals and makes a finer flower for warm weather use.

Kaiserin Augusta Victoria-This is one of the grandest of all roses. It is a strong, vig. orous grower, producing buds and flowers of enormous size. Color pure ivory white. We have no hesitancy in saying that this rose is 
unequaled by any other in its color. A grand garden rose on account of its vigorous growth and hardiness.

Bessie Brown-This rose is considered one of the finest of the roses of late introduction, and is well worthy of the place it occupies among roses. It is of the Hybrid Tea class and will stand frost if slightly protected. Blooms are enormous size; of heavy substance and perfect shape, lasting splendidly when cut. The color is snow-white, faintly flushed and tinged with pink. A fine, strong free growing, producing long stems.

Frau Karl Druschke (White American Beauty)-Form of flower identical with American Beauty. Color clear white, beautiful in bud and half open.

The Bride-This is decidedly the most beautiful white tea rose. It is a sport from Cather. ine Mermet with which it is identical in growth and shape of flowers. The flowers are very large and double, on stiff stems of fine texture and substance, and last a long time after being cut; makes one of the best varieties for corsage wear or bouquets. During extremely hot weather it becomes a pinkish white; at other times a beautiful pure white.

White Cochet-The charming new white toa rose. Another new American rose. Its habit is exceedingly strong and upright, like its parent, Maman Cochet. It possesses the same large, beautiful, healthful foliage, and it is a most profuse and constant bloomer. The flowers are of enormous size, round and delicately tea-scented. It is without doubt the largest white rose, both in bud and flower.

White Malmaison-The best everblooming white rose. Pure white; best rose for designs and floral offerings. Growth and habit same as the Pink Malmaison.

White Ophelia-Erect habit, faultless form, stiff long stems; handsome bright foliage; pure white; a perfect rose.

Marie Guillot-This beautiful Tea Rose continues in popular favor, and still maintains its position as one of the best white roses of its class; flowers of an unusual style, entirely double to the center; very sweet-scented.

\section{Climbers}

Climbing American Beauty-A seedling of American Beauty crossed with Wichuriana. Same size, color and fragrance as American Beauty. A vigorous climber. Good foliage and profuse bloomer.

Climbing Helen Gould-Probably no red rose has held its place in the heart of rose lovers for so long a period as has the beautiful Helen Gould. We have now the pleasure in introduc. ing this famous rose in a climbing form. Every. one is familiar with this warm-watermelon red color of its charming flowers. This is a grand climber.

Climbing Etoile de France-Brililant red, crimson velvet. Centering to vivid cerise. Identical with Etoile de France, except in its vig. orous climbing habit.

Christine Wright-This sister to Climbing American Beauty is an equally strong grower, and produces a great burst of large, double wild-rose-pink flowers, borne individually and in clusters, and of the most attractive quality. Occasionally additional flowers appear later in the season. The foliage is thick, leathery, and almost entirely immune from attack by insects or disease.

Emily Gray-In this we have a real yellow climbing Rose as hardy as Dr. Van Fleet. The buds are long and pointed, of splendid shape; in color a beautiful light orange--yellow, changing to pale orange as they expand; they are borne on stiff stems of sufficient length for cutting; these stems are of a crimson-red color which together with the unusually dark green, glossy, holly-like foliage, adds a charm, to the flowers and makes the plant, even when out of bloom, a most ornamental subject.

Climbing Kaiserin Augusta Victoria-Flowers same as the Kaiserin, which is too generally known to require description here. Stout canes, very quickly covers verandas, etc. Always in bloom.

Climbing Killarney-A vigorous climber otherwise possessing all of the splendid qualities of the parent Killarney.

Climbing Meteor-Is of strong, vigorous habit of growth, producing in great profusion throughout the season magnificently formed buds and flowers, which in color are of a dark velvety crimson, the equal of any rose in cultivation, and possibly more glowing than its illustrious parent.

C1 Maman Cochet-Same as Maman Cochet a strong pink climber and good bloomer, flow. ers are double and keep well.

Crimson Rambler-The most popular out-ofdoor climber of today; a rapid producer of long, heavy canes, reaching a height of ten to twenty feet in one season; rich clusters of bloom form a mass of vivid crimson beauty until late in the season. Perfectly hardy in the most trying climates, being a native of Japan.

Reine Marie Henriette-A congenial compan. ion to the Marechal Niel; a sturdy climber and everbloomer, thriving especially well in the South. Elegant in bud, with large, full, finely formed flowers of rich brilliant crimson.

Dorothy Perkins-Beautiful, hardy pink, blooming in clusters. An extra good climber for the South.

Doctor Van Fleet-One of the newer type of climbers which combines absolute hardiness with flowers large, as in the tea and Noisette class. This variety shows a mass of beautiful clustered buds, which open out into large, shapely flowers; delicate; flesh white. An admirable cutting variety with stems 12 to 18 inches long.

Flower of Fairchild-A counterpart of crimson rambler in every respect, except that it shows ever blooming tendencies.

La Marque-A rampant climber; large clus. ters of full, very double and sweet pure white flowers. A beautiful rose for which there is always a great demand.

Marechal Neil-Beautiful, deep yellow; very large, full globular form, sweet, free bloomer; the finest climbing rose; two years, budded.

Veilchenblau-The blue rose. Color steelblue or amethyst, sometimes reddish lilac; a seedling of Crimson Rambler, with double florets in fine clusters. It is probably the most beautiful grower, with handsomest foliage of any climbing rose in existence; the leaves are exceedingly long and slender, with high gloss. Indications point to its becoming a very popular novelty. 


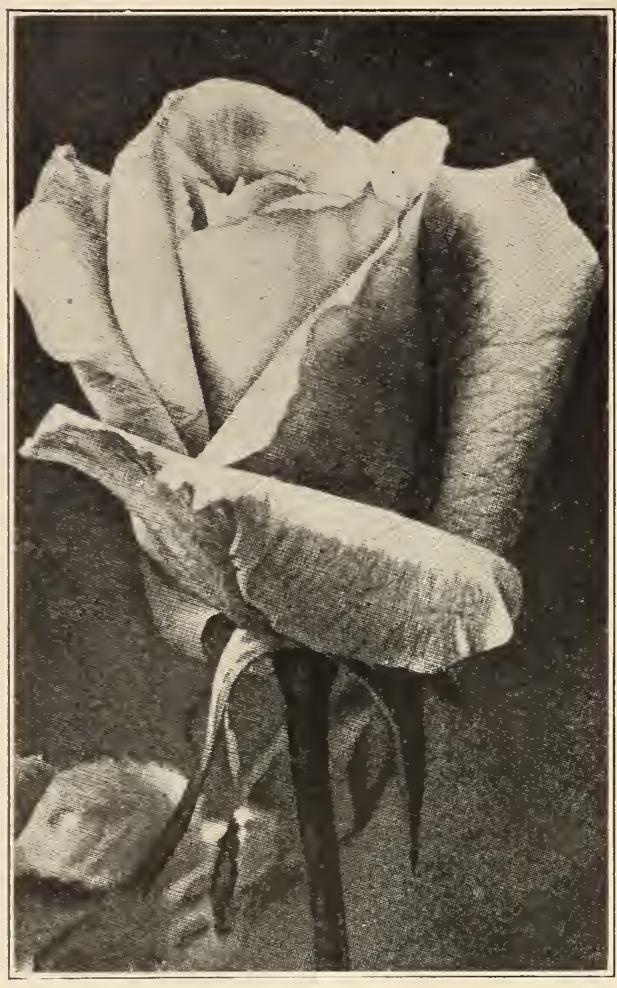

Tausendschoen-Soft pink, blooming in clus ters. The branches look like large pink ostrich plumes; a splendid forcing variety under the same treatment given the Crimson Rambler. Very valuable.

Yellow Banksia-Yellow, small flowers; very fragrant. Both Banksia roses are very hardy

Climbing Wooten-One of the best of the red climbers. Blooms large and full. Crimson shaded with almost violet crimson. Strong grower, good foliage and profuse constant. bloomer.

\section{NEW ROSES}

Strong two years, $\$ 1.00$ each; $\$ 10.00$ per dozen.

Souv. Claudius Pernet-One of the most interesting roses ever introduced to the trade. It holds a proud place in the cut-flower market. A "Golden King of Roses" for all who have learned to grow it well; foliage like Holly; continues in bloom, wonderful in build, color and size.

As a cut flower, its keeping qualities are marvelous and the buying public has found it out, and now ranks it with American Beauty as a Rose de Luxe.

Miss Lolita Armour-Winner of the coveted Bagatelle gold medal in 1921. The flowers are of large size, fully double, deliciously fragrant, with petals of great substance, the basic color being deep coral with a golden and coppery red suffusion, the base of petals a rich golden yellow with copper-red sheen.

David O. Dodd-A new crimson Rose with great possibilities as a bedder. A magnificent rich crimson, flushed scarlet, with well shaped buds, carried erect and opening into a large beautifully shaped flower. Very free flowering; growth bushy and upright.

We consider this fine Rose to be one of the best of its color, a great advance on all other crimson bedding varieties and certainly it is destined to become a great popular favorite. A splendid Rose with no apparent faults.

Rosarie-A great improvement on the popular Thousand Beauties (Tausendschon), and consequently a welcome addition to this section. While it has the same habit of growth and general characteristics as Thousand Beauties, the color is superior-a deeper and more even shade of cerise-pink or carmine. Those who have admired Thousand Beauties will surely add this improved variety to their collection because of its lovely coloring.

Mary Wallace-Introduced in 1924 by the American Rose Society. Vestal \& Son was one of a select number of prominent Rose growers favored by participation in this first distribution of new Roses through the Federal Bureau of Plant Industry and the American Rose Society. The late Dr. Van Fleet, who originated such choice climbing varieties as "American Pillar," "Silver Moon" and "Dr. Van Fleet," has bequeathed to posterity the fruits of his latest efforts directed towards perfected "dooryard" types. Mary Wallace is the first of this series to be released under Federal control, even the description and price of which is regulated under contract, to be as follows:

"Mary Wallace. (W. C. 124). Pillar Rose type. Makes a fine, strong, self-supporting Rose 6 to 8 feet high, with large, glossy foliage, resistant at Bell to all diseases. Blooms with great freedom in spring, and bears a considerable number of fine buds in summer and fall. Flowers well-formed, semi-double, bright clear rose-pink, with salmon base to the petals. Largest in size of any Wichuriana hybrid, generally exceeding 4 inches in diameter."

Irish Fireflame-HT. (A. Dickson \& Sons, 1913.) A very large, single flower of deep maddery orange, opening from spiral buds, passing to rich satiny old-gold veined with crimson.

Hortulanus Albert Fiet-Per. (M. Leenders \& Co., 1919.) Mme. Melaine Soupert $\times$ Paul Lede. Buds long, apricot-yellow, with coppery edges; flower salmon-rose. Growth medium; very floriferous.

Eldorado-Per. (Howard \& Smith, 1922.) Unnamed seedling $\times$ Mme. Edouard Herriot. Golden yellow, with the peculiar tint of Marechal Niel, base of the petals slightly tinted red. Large flowers of distinct formation. Free flowering and very fragrant.

Golden Emblem-Per. (S. McGredy \& Son, 1917.) Flower similar in color to Constance, same crimson stripe on outer petals, high pointed center, tea perfume.

Imperial Potentate-HT. (Clarke Bros., 1923.) Deep shining rose-pink shaded lighter on reverse of petals; fragrant.

Cl. Hoosier Beauty-HT. (Howard Rose Co., 1918.) Deep crimson with darker shadings, just like the bush variety, and is strong and vigorous. We believe this is one of the very best Hybrid Tea climbers ever produced.

Cl. Sunburst. HT. (Stuart, Low \& Co., 1914.) Same as the well-known bush. It is strong, vigorous and quite hardy. Recommend it to your customers every time. 


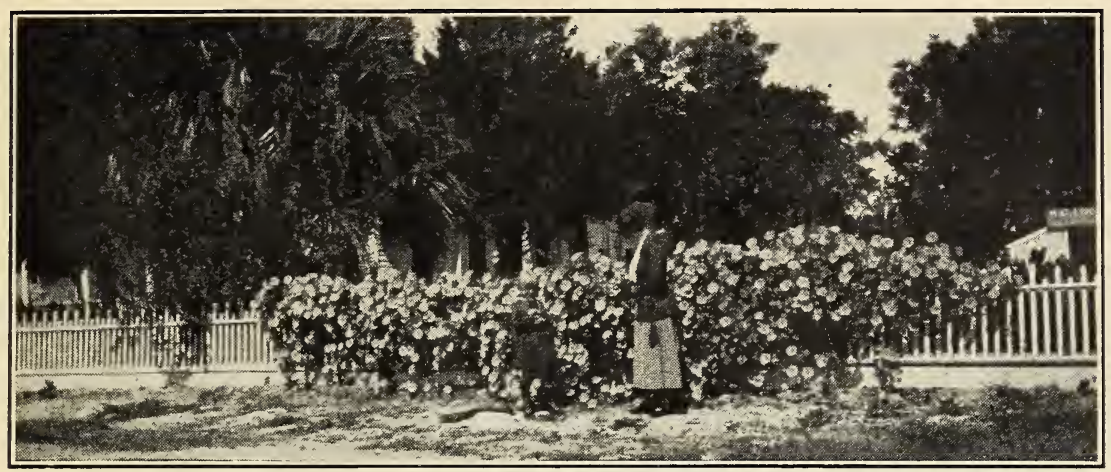

Heavenly Blue Morning Glories

\section{Climbing, Clinging and Creeping Plants}

These long-lived plants are the most popular and best for the South to cover arbors, galler. ies, old trees, etc., in a very short time.

Bignonia Grandiflora-Giant flowering trum. pet Vines. 2 year, strong plants, $\$ 1.00$ each.

Kudzu-The famous Chinese Kudzu grows more in three months than most vines do in five years. Adaptable to porches, arbors, fences, rockeries, old trees, etc. If you wish a vine that will grow anywhere in the bed or poorest soil, then plant the Chinese Kudzu. The large, bold, green leaves afford a dense shade. The clus ters are deliciously fragrant. 25 cents each, $\$ 2.50$ per dozen.

Ampelopsis Veitchii (Boston Ivy)-This plant resembles very much our ivy, but grows very rapidly, covering a large wall in one season. The foliage is small and neat and blood. red in color in fall. 35 cents each.

Ivy, Hardy English-The hardy evergreen vine that remains so all the year, making it one of the most valuable of all hardy vines. It is used in covering walls and has become popular for covering graves, especially in the shade where grass will not succeed. Price, 25 cents each, pot grown.

Antignoum Leptophus (Queen's Wreath)-A splendid plant from Central Mexico, producing rose-colored flowers in racemes two feet long. The profusion of bloom is such as to give the resemblance of roses at a distance, hence its name, "Rosa de Montana," or Mountain Rose. Will live out in the winter anywhere in the South. The vines are killed by frost, but it quickly shoots up in the spring and develops its flowers from May until frost. This is one of the most lovely vines. Bulbs, 25 cents each Smaller bulbs, 15 cents each.

Clematis Paniculata-One of the most beautiful of our hardy climbing vines. The flowers are pure white, and are borne in great panicles or clusters of bloom, which fairly cover the plant so that a mass or sheet of fleecy white. The fragrance is delicious, resembling the Eng. lish Hawthorne blossoms, and so subtle and penetrating that a large plant in bloom fills the air with exquisite fragrance. 25 cents each.

Clematis Drummondi-Many varieties of Clematis grow wild in Texas. Among them this is the best. When in bloom the plant is covered with white flowers, which come in such profusion that it attracts attention along fences in the moonshine, being as white as cotton. Flowers are not tragrant. A rapid climber. Strong plants, 25 cents each.

Wistaria Senesis (Purple Wistaria)-A quick. growing climber, producing long racemes ot purple flowers. 35 cents each.

Wistaria Sensis (White Wistaria)-A long, drooping cluster of pure white color, very elegant, strong two-year plants. 35 cents each.

Vinca, Evergreen (Trailing)-Dark green, 15 cents each; $\$ 1.50$ per dozen.

Vinca Varigata-Shaded green and white. 25 cents each.

Vinca Harrisemii (Trailing)-Two shades of green and gold. Strong plants, 15 cents each; $\$ 1.50$ per dozen.

\section{Honeysuckles}

Prices 35 cents each; $\$ 3.00$ per dozen.

Coccinea-Flowers red, good bloomer; stands Texas sun well.

Halleana-One of the finest Honeysuckles grown. Blooms from May till November; is always evergreen and one of the most fra. grant; flowers white, changing to yellow.

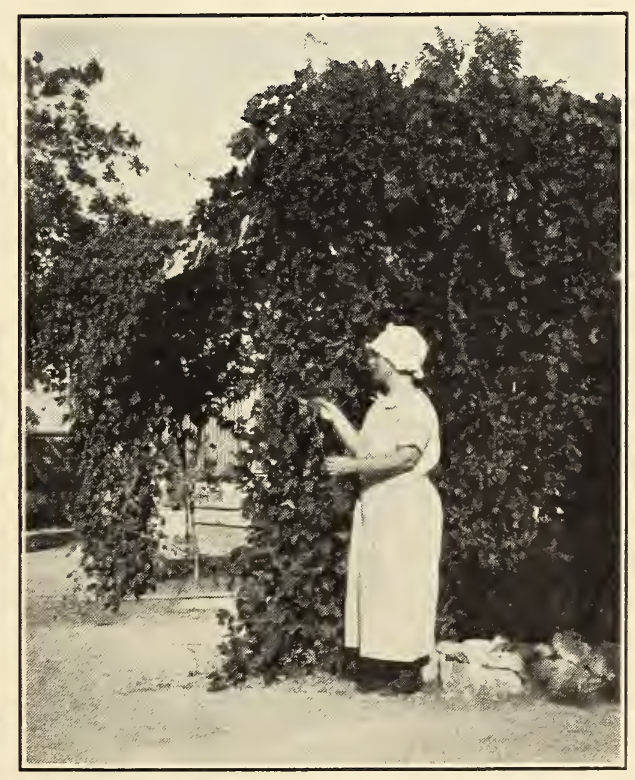

Chinese Kudzu Vine 


\section{Ornamental Grasses}

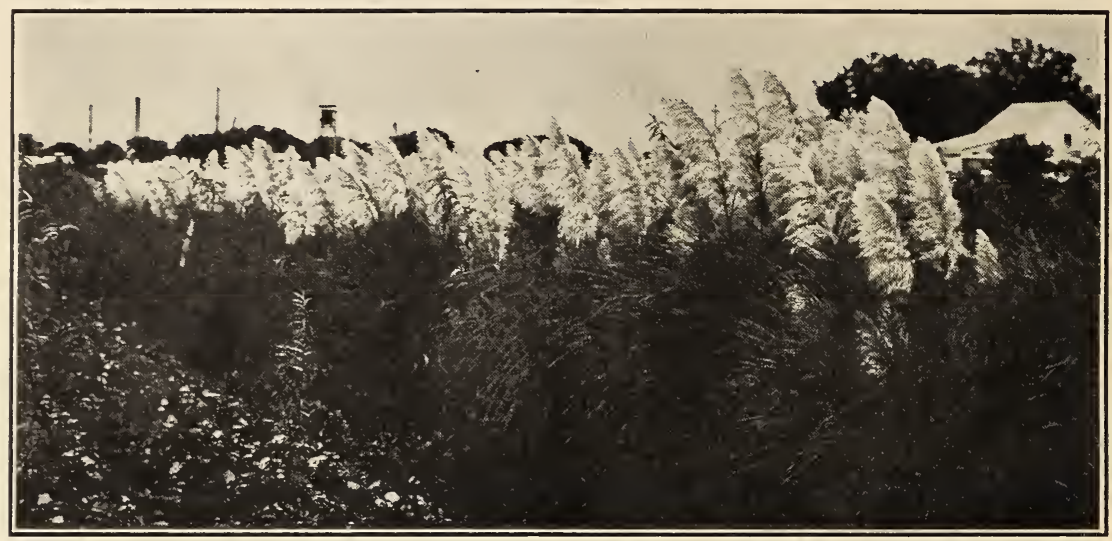

Pampas Grass

\section{Zebra Grass}

No garden is complete without a few of these beautiful grasses. They are so easily transplanted and grow with so little care that every. body can afford to have them. The beautiful plumes they produce keep for years if cut at the right time and properly dried. $15 \mathrm{c}$ each.

Eulalia Japonica Variegata-A variegated hardy grass from Japan. In appearance it somewhat resembles the Ribbon Grass while in a young state. It forms compact clumps. Its flower stocks are very graceful and numerous. 15 cents each.

Eulalia Japonica Zebrina (Zebra Grass)Bright green blades with yellow bars across them; grows to a height of 5 to $6 \mathrm{feet}$; produces fine-lace-like plumes which last for years if cut when fresh; perfectly hardy. 15 cents each.

Eulalia Univittata-Plumes silvery white, produced upon very long stems; blooms early; a graceful new variety, 4 to 5 feet. 15 cents each.

Umbrella Plant (Cyperus Alternifolius)-A splendid plant, throwing up stems two or three feet high, surmounted at the top with a whorl of leaves diverging horizontally, giving it a novel appearance. Fine for center vases or aquariums. Price, 25 cents each.

Gynerium Argenteum (Pampas Grass)Enormous bunches of long, handsome, dark green blades, producing long stalks of silver. white plumes, grow light. 50 cents each.

\section{Cannas}

Dry, divided roots, the best to transplant, 15 cents each; $\$ 1.50$ per dozen, except where noted.

This is one of the most thankful flowers. It produces its flowers from spring until frost kills the tops of the plant, and in such different and exquisite colors that nobody can help admiring them. The plant needs plenty of watering, and can only be had where there is a plentiful supply of same.
David Harum-Foliage bronze, height 3 feet, growth sturdy, habit moderately clean, flowers similar to King Humbert, but color is reddish yellow orange.

King Humbert-Foliage bronze, height 3 feet. The finest bronze-leaved Canna. A gorgeous thing. An orange scarlet flower streaked with crimson and gold. True crchid type.

Alemania-The giant of all Cannas. Produces the largest flowers. The outer petals are scarlet, with a very broad, golden yellow border; inside of bloom is scarlet and dark red.

Austria (New)-The gorgeous new orchidflowered Canna; a hybrid with "Canna Flaccida" as one parent. Flowers of immense size, 5 to 6 inches across. Color golden yellow.

Feuermeer-Dark red, medium height, good bloomer.

Hungaria-Fine rosy pink, very free bloomer.

Eureka-The best white canna for all purposes, large substantial flowers, very freely produced on strong vigorous plants.

City of Portland-A wonderful bright rosy pink, much deeper in color than Hungaria, a free flowering, vigorous growth.

The President-Immense florets of bright red color insured its immediate popularity.

Fanal-An intense fiery cinnabar red, that compels attention, an ideal grower, producing a great abundance of flowers on upright stems, well above the foliage, a fine bedder.

Mrs. Alfred Conard-One of the very best cannas in commerce today. Large, exquisitely shaded salmon, pink flowers in great abundance, upright stalks.

Orange Bedder-Superior to all preceding varieties of this color, bright orange with just enough scarlet suffusion to intensify the daz. zling mass of color.

Rosea Gigantica-Large flowers, beautiful rose pink color. 


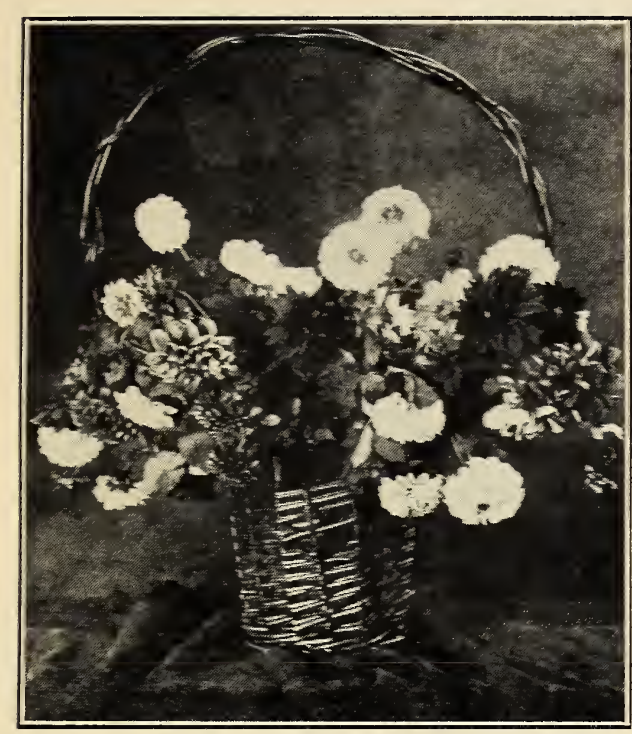

Dahlias

\section{Bulbs}

Amaryllis Johnsonii-Brilliant red flower, 5 iuches in diameter, with a distinct white stripe in the center of each petal; rery fragrant. 35 cents each. Large bulbs, 50 cents each.

Crinum Lily-Nice strong bulbs of these beautiful summer blooming outdoor lilies. Wine and milk colored. 25 cents each, $\$ 2.50$ per dozen.

German Iris (Flag)-Color ivory white and blue; very hardy. 15 cents each; $\$ 1.50$ per dozen; $\$ 10.00$ per 100.

Gladiolus-Blooms only once, and although its beauty lasts only a short time, it is beloved by everybody who knows it. The flowers are borne on spikes 2 to 3 feet long and blooms in success for 8 to 12 days, the lower flowers blooming first. To hare a continuance in bloom the bulbs ought to be planted at intervals of every two weeks from March 1 until the end of May. My bulbs are extra large, well ma. tured and taken only from the best rarieties. Bulbs, extra large, of the finest rarieties that money can buy. 35 cents per dozen; $\$ 2.50$ per 100.

Try a hundred of my extra large and extra fine bulbs, and have the grandest flowers you ever saw in colors.

We can furnish the following named rarieties large bulbs, true to name.

America-A fine pink variety, much used by florists, opens well. Price, j cents each; 50 cents per dozen.

Velvet King-The best Scarlet Gladiolus. 5 cents each; 50 cents per dozen.

Francis King-Beautiful vermilion-scarlet. very useful for cutting. 5 cents each; 50 cents per dozen.

Chicago White-The pure White Gladiolus. rare. 5 cents each; 50 cents per dozen.
Caladium Esculantum (Elephant's Ear)-One of the most effectire plants in cultiration for the flower border or for planting out upon the lawn. It will grow in any good garden soil, and is of the earliest culture, but to obtain the best results it should be planted in rich com. post and plentifully supplied with Fater. Price, medium bulbs, 25 cents each; $\$ 2.50$ per dozen. Large, 00 cents each. Fancy Leaf Caladium, nice bulbs. Price, 50 cents each.

Mexican Tuberoses-Unlike any other variety it has stiff, tall stems; flowers pure white, single, delightfully fragrant, blooms continu. ously. Invaluable either for pots or open garden. Large bulbs, 5 cents each; 25 cents per dozen, \$2.00 per 100.

Yellow Day Lily (Hermerocallis Formosiss!. ma) - One of the hardiest of all lillies; single. Once planted you have it always. Rich gold color, striped inside. Price 10 cents each; $\$ 1.00$ per dozen.

\section{Peonies}

Peony-We hare bulbs of the very best varieties, double, in difierent colors. No. 1 bulbs, 50 cents each; $\$ 5.00$ per dozen.

\section{Dahlias}

Strong bulbs, 25 cents each; $\$ 2.50$ per dozen; $\$ 20.00$ per 100 , except where noted.

Another beautiful perennial of great magnificence, raising its brilliantly colored flowers on lofty stems. We have only the rery latest and best varieties.

For many years we have tried to get the Dalhia true to name, and have never succeeded in getting them until this rear. We purchased the highest priced varieties from the Dahlia King at Bridgewater, Mass., of the Dahlias that Were awarded the first prize at the World's Fair at St. Louis, and we are now able to furnish bulbs of highest quality and true name. We hare secured them directly from the Dahlia King regardless of price, and are sure our cus. tomers would rather pay a little more and get the rery best than any others.

The Dahlia thrives best in a sunny location with ordinary soil.

Mina Burgle-Beautiful, deep glowing crim. son; finest crimson rariety in existence; good for cut flower purposes, haring long stems and being extra free bloomer.

Maud Adams-The color is pure white, very effectirely orerlaid clear, delicate pink. This wonderful variety is unsurpassed in quality in every respect, in reality, a model of perfection. The most popular variety for florists. I cannot recommend this rariety too highly.

Oregon Beauty-Originated by an Oregon seed firm. A seedling from $\bar{m}$. Agnew. Color a glowing fiery scarlet.

Souvenir de Gustav Douzon-Orange, red, extra large flowers. One of the best.

\section{Cactus Dahlias}

Clara G. Stedwick-Clear, bright salmon; large and very free.

George Walters (Cactus) - The most wonder. ful dahlia efer offered. Bright salmon pink color, artistically suffused with old gold. It 
is the largest Hybrid Cactus Dahlia ever introduced. The flowers are borne on long stiff stems well above the foliage. It won first prize at the Dahlia show last summer. Price, 25 cents each.

J. H. Jackson-This is the best dark Dahlia yet out, almost black.

Kriemhilde-Pleasing shade of pink, white center. Extra.

Mrs. C. H. Breck-A new hybrid Cactus Dahlia of exceptional merit. Color creamy passing to various shades of rose pink. 25c.

\section{Show and Fancy Dahlias}

Dr. J. P. Kirkland or Cuban Giant-Dark crimson, large and free.

Fascination-Rose pink, large. One of the best.

Robert Broomfield-Pure white, large flower free.

Storm King-Pure snow white. One of the very best, very free.

Stradella-This is one of our seedlings and can be highly recommended. The color is rich deep purple crimson. 25 cents each

\section{Holland Peony Flowered Dahlia}

Leo XIII-The habit of this plant is all that can be desired, producing large flowers upon splendid stems, well above the foliage. Beautiful deep yellow. 25c.

\section{Flowering Plants}

Golden Glow-This plant attains a height of 3 to 4 feet and blooms from July till fall. Easy to grow. Strong bunches, 25 cents each, $\$ 2.50$ per dozen.

Tritoma, Everblooming-The greatest plant ever introduced, surpassing the finest Cannas for attractiveness and brilliancy, equal to the Gladiolus as a cut flower, and blooms inces santly from June until December. Plants are hardy in open ground. Strong roots. 25 cent each; $\$ 2.50$ per dozen

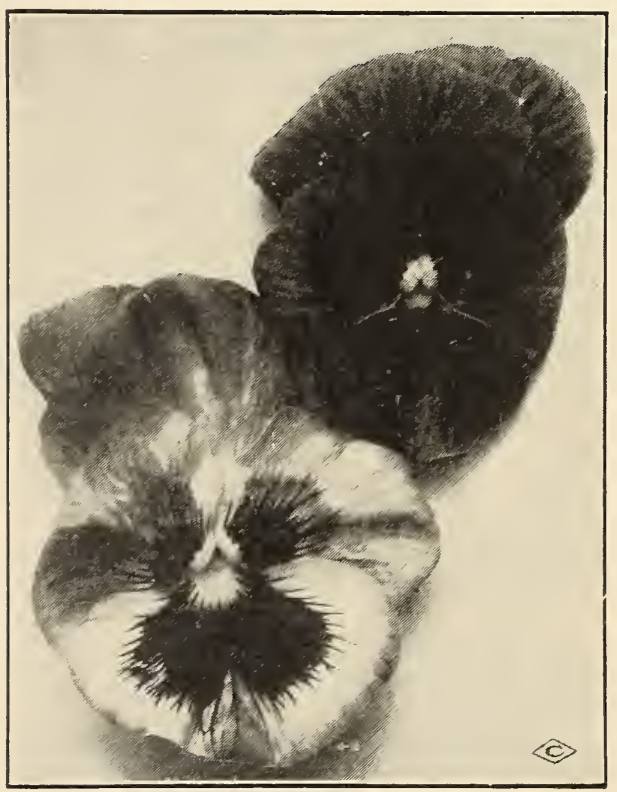

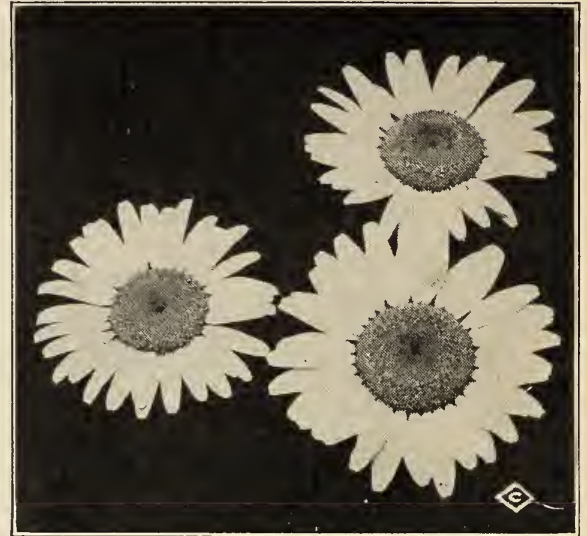

Shasta Daisies-Burbank's great production. Largest flowers and constant bloomers of all daisies. Wonderfully hardy, especially in summer. Strong plants. 5 cents each; 50 cents per dozen.

Malvaviscus Drummondii-A native of Texas. producing during summer a profusion of nice scarlet flowers and edible fruit. 25 cents each; $\$ 2.00$ per dozen; $\$ 15.00$ per 100 .

Sweet Williams-Best mixed, strong plants. Per dozen, 25 cents.

\section{Carnations}

The Carnation excels all other flowers, the rose alone excepted. If planted in the open ground it will bloom all summer, and if taken out and brought indoors at the approach of cold weather, it will bloom in winter.

Mixed Color (Seedlings)-Grown from the very best Italian seed. 35 cents per dozen.

Large Named Varieties-10 cents each, $\$ 1.00$ per dozen.

\section{Violets}

Prince of Wales (New Single Violet)-This violet is far ahead of any violet known. It is wonderfully free-flowering. with stems from 10 to 12 inches long; large, green leaves of thick leathery texture. The grand single flowers of a true violet color that does not fade, are of round symmetrical form, almost as large as pansies, and of the richest and most delicate fragrance. 5 cents each; 50 cents per dozen.

\section{Hollyhocks}

Best varieties, in all colors, strong plants. 15 cents each; $\$ 1.50$ per dozen.

\section{Pansies}

Giant-Flowering Pansies (Viola Tricolor Maxima) - I have imported the finest mixed pansy seed that I could get in Europe, and have very strong plants to offer at 20 cents per dozen; $\$ 1.50$ per 100 plants.

We have a large stock of Pansies and Carnations.

Phlox-Hardy; fine clumps in different colors-red, pink, white and violet color; will grow on any soil and live and flower freely for many years. 25 cents each; $\$ 2.50$ per dozen.

\section{Bananas (Musa)}

Orinoco-The hardiest and commonest sort. Plants of large size with dark green leaves, very robust and easily grown. Strong suck. ers, $\$ 1.00$ each. 


\section{Flower Seeds}

\section{NATURE'S MIRACLE}

"I paid a dime for a package of seeds And the clerk tossed them out with a flip.

"We've got'em assorted for every man's needs," He said with a smile on his lip,

"Pansies and poppies and asters and peas:

Ten cents a package! And pick as you please?"

Now seeds are just dimes to the man in the store,

And the dimes are the things that he needs:

And I've been to buy them in seasons before,

But have thought of them merely as seeds;

But it flashed through my mind as I took them this time,

"You've purchased a miracle here for a dime!"

"Iou've a dime's worth of power which no man can create,

You've a dime's worth of life in your hand:

Iou've a dime's worth of mystery, destiny, fate. Which the wisest cannot understand.

In this bright little package, now isn't it odd? You've a dime's worth of something known only to God:" -Edgar A. Guest.

All the flower seeds that I offer are guaranteed to be fresh and of the highest quality. All seeds are now grown by us.

Aster seeds-We have grown for the last two years beautiful, double, large branching Asters and having received so many inquiries for good seed, we are glad to offer this year seed of the best mixed varieties at 25 cents per package.

Globe Amaranth-Very hardy straw like flower, easy to grow, fine for cut flowers in the hot summer months. Per pkt., 10 cents.

Corn Flower (Centuarea Imperialis)-Purple. good summer bloomers. Per pkt., 10 cents.

Cosmos Klondyke-A gorgeous orange yellow flower with very handsome foliage; more coarsely lacinated than others. Per pk., 10c.

Hollyhocks-Large double mixed, extra fine. Per package, 10 cents.

Pansy-The best mixture of giant-flowering kinds, all colors. Large package, 20 cents each.

Zinnias-Large collossal flowers. No other flower will stand the summer heat as well as the large Zinnias. They should be planted every month during summer to have flowers until frost. Our Mammoth Collossal Zinnias were admired by all visitors. We have them in a fine mixture of all the best colors. 10 cents per package.

In named varieties, separate colors as foi. lows:

White, Golden Yellow, Sulphur Yellow, Flesh Color, Crimson, Scarlet and Purple.

15 cents per package.

Zinnias, Dahlia Flowered-The plants of this new race are very sturdy and produce many flowers with stout stems. In formation the broad petals are closely imbricated, sometimes almost seeming to be piled one upon the other. The flowers often measure 6 to 8 inches in diameter. Mixed, of the six best named varieties, $25 \mathrm{c}$ per pkt.

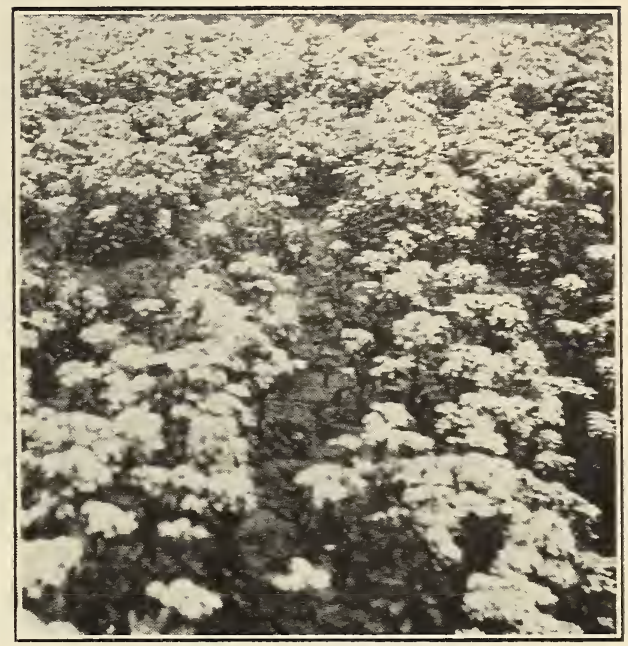

Candytuft for Seed Only.

Delphinium-Double, in white, pink and mixed. No other spring flower will give so much joy as a bed of double Larkspur. Fine for city parks. 10 cents per package.

Antirrhinum (Snapdragon)-Najus grandi. flora. Per package, 10 cents.

Scabiosa (Mourning Bride)-Sweet Scabious. Very desirable for summer cut flowers. Use. ful in making up. Very hardy and can stand our long hot summer well. Per package, all colors, mixed, 10 cents.

Sunflower (Helianthus)-Double Chrysanthemum flowered. Rich golden yellow flowers perfectly double, resembling a Chrysanthemum. Per pkt., seed, 10 cents.

Marigold-French, drawf. Form dense bushes and bloom through the entire summer. Price per pkt., 10 cents.

Sweet Peas-Grandiflora and Spencer Sweet Peas of the very best varieties. Price 15 cents per package; per pound, $\$ 2.00$.

Dianthus Chinensis (Chinese Pinks) - Very best, mixed. 10 cents per package.

Dahlia Variabilis-Double mixed. 15 cents per package.

Dianthus Caryophyllus Barbatus (Sweet Tilliam)-Package, 10 cents.

Balsams-Improved rose, extra double. 10 cents per package. (Home grown).

Heavenly Blue (Morning Glory)-Seed 10 cents per package.

Cypress Vine-A most beautiful climber with delicate dark green, feathery foliage and an abundance of bright, star-shaped scarlet and white blossoms. 10 cents per package.

Verbenas-Giant flowered. 10 cents per package.

Vinca Rosea-Red and white mixed. 10 cents each.

Texas Blue Bonnett-Seed 10c per package. 


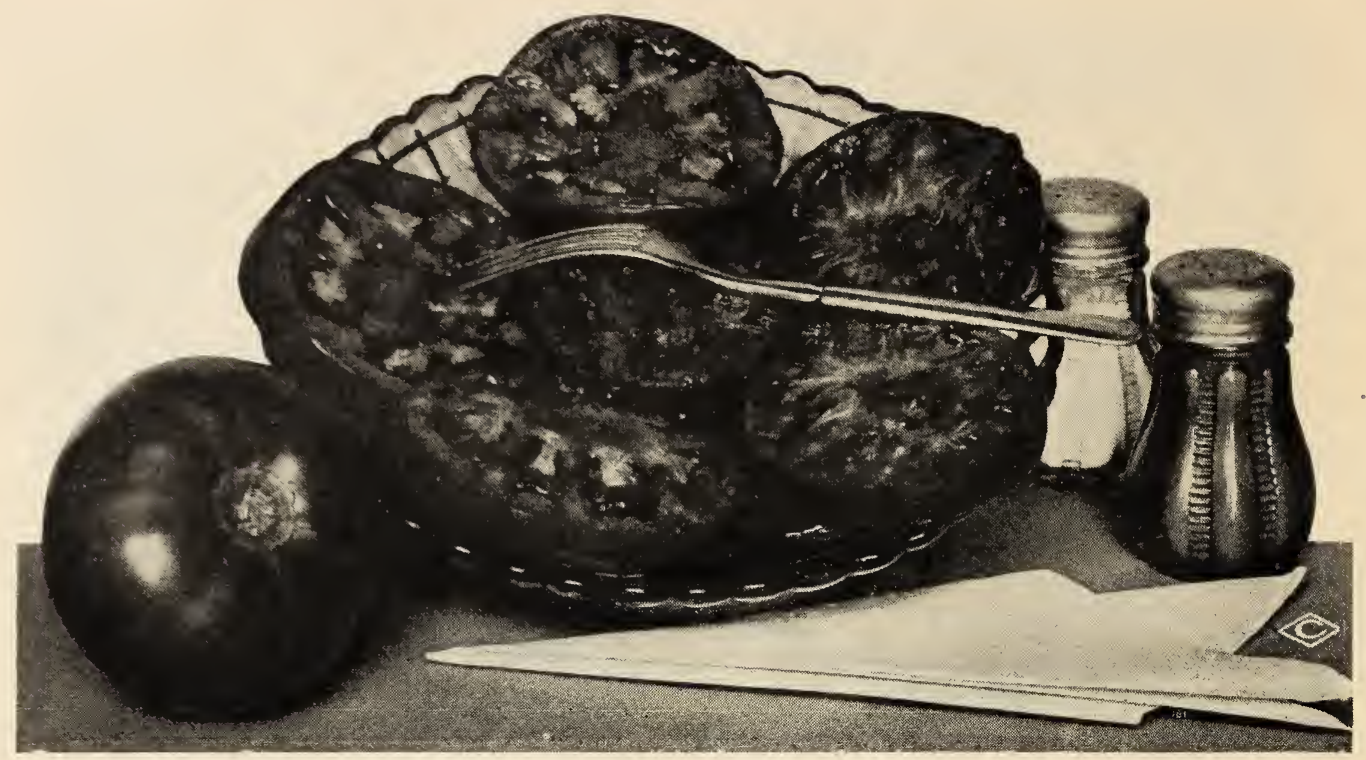

\section{Vegetable Seeds}

Tomatoes-For many years I have devoted a great deal of my time in testing the old and new varieties of tomatoes, as they are introduced, and among them all I have found only two varieties that I can highly recommend as the best for the Southland. All those who have planted seeds from the President Roosevelt and our new Triumph Pink Tomato know that they are the best ever offered in the South. We are the largest tomato seed growers in the South, and take seed from choice, full-ripe tomatoes.

Tomato, President Harding-This new tomato originated on our grounds; outyields and outsells any tomato on the market. The yield of President Harding is marvelous. Produces at every joint, large clusters of large, smooth, firm, beautifully shaped fruits, uniform in color shape and size. At times the vines are so full that they can hardly hold all the fruit that they produce. They ripen evenly and color up well; keep vigorous and green until frost. The skin of this tomato is tough and meat tender; a solid mass of red meaty flesh. Is a good shipper and a good cropper. Another point of this new tomato is that it is blight resistant. We can furnish on application, testimonials of some of our best friends who planted a few plants last spring to test this new tomato at Lockhart, San Marcos, San Antonio, Palestine, etc., and all say it is the best tomato they ever planted, so this variety has been thoroughly tried before we put it on the market. Our San Marcos Friend writes: It is the best tomato that I ever saw and that I ever planted. Price, per package seed, 25c; oz., \$2.00; per pound, $\$ 25.00$.
Locke's New Triumph Pink Tomato-This tomato is an improved McGee tomato, having been selected and grown from the best pink tomato which was selected from a lot of Prof. N. C. McGee's variety which bears his name. As Prof. McGee's tomatoes were of different shades of pink and red, we have so improved this tomato that the plants grown from our seed will all produce pink tomatoes of large size. The tomato is round and smooth, and immensely productive, of large size. This variety is unexcelled for black land. Uniform packages containing about 1,000 seeds, 15 cents each; per ounce, $\$ 1.00$; per pound, $\$ 15.00$.

Tomato, President Roosevelt-The earliest, best and most productive of all the round, smooth, large tomatoes existing. Upon several years' trial we found the new tomato President Roosevelt, the earliest, best, smooth, new tomato up to now existing. It is immensely productive, nearly all meat, having very little seed; firm and of very mild flavor. The growth of the plant is very vigorous, 5 to 6 feet high; the foliage is large, the bright, scarlet, solid fruits weigh on an average of 1 pound each; in clusters of 4 to 8 . Packages, 15 cents each; per ounce, $\$ 1.00$; per pound, $\$ 15.00$.

Cucumber, Locke's New Ideal-The best cucumber ever grown in Texas. Improved by us and acclimated to our conditions. Very vigorous and healthy, and grows throughout the summer. We raised the finest green cucumbers in the middle of July and August. Flesh white and crisp, of excellent flavor. Early, and immensely productive. Color is dark green with pale green stripes. Without doubt the best cucumber for the market gardener. Splendid for fall planting. Package, 10 cents; 1 ounce, 20 cents; $1 / 4$ pound, 75 cents; per pound, $\$ 1.50$. 


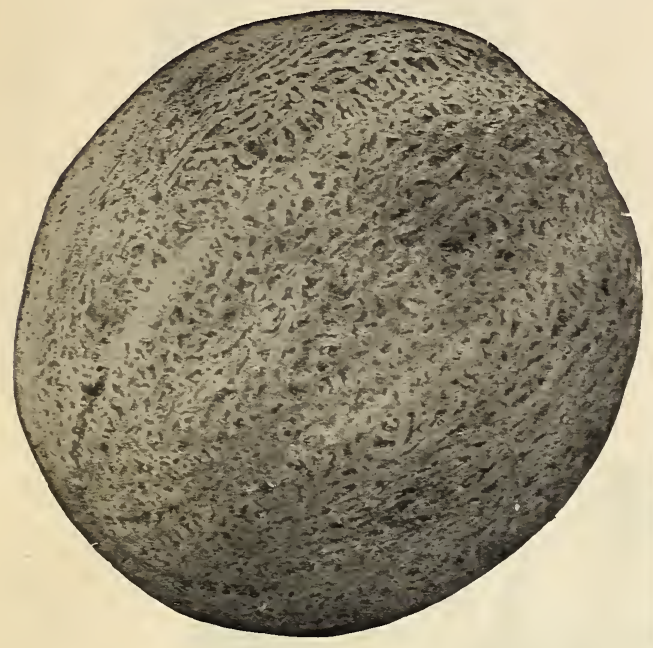

\section{Melon Seeds}

Alabama sweet-The best watermelon for sandy soil. All our melon seed is taken from selected melons. 10 cents per ounce; 75 cents per pound.

Tom Watson-Best watermelon introduced to date. Perfect in shape; no strings; delicious in taste; splendid shipper. Package, 10 cents; 1 pound, 75 cents.

\section{Cantaloupes}

Rocky Ford Cantaloupe-The best cantaloupe for the Southwest. Too well known to need any further description, home grown seed Price, per ounce, 10 cents; per pound, 75 cents.

\section{Feed Seeds}

Surecropper-White, early, quick maturing, sure enuf drought resisting and a crib filler even in hard years. Is not only a magnificent corn for early spring planting, but a better corn for summer planting was never known. $\mathrm{Pk}_{\text {., }}$ $75 \mathrm{c}$; 1/2 bu., $\$ 1.50$; bushel, $\$ 2.75$.

Yellow Dent-Ferguson's famous variety. It is surely the best yielding big grained yellow corn that the southwest has ever known. Pk., 75 c; 1/2 bu., $\$ 1.50$; bushel, $\$ 2.75$.

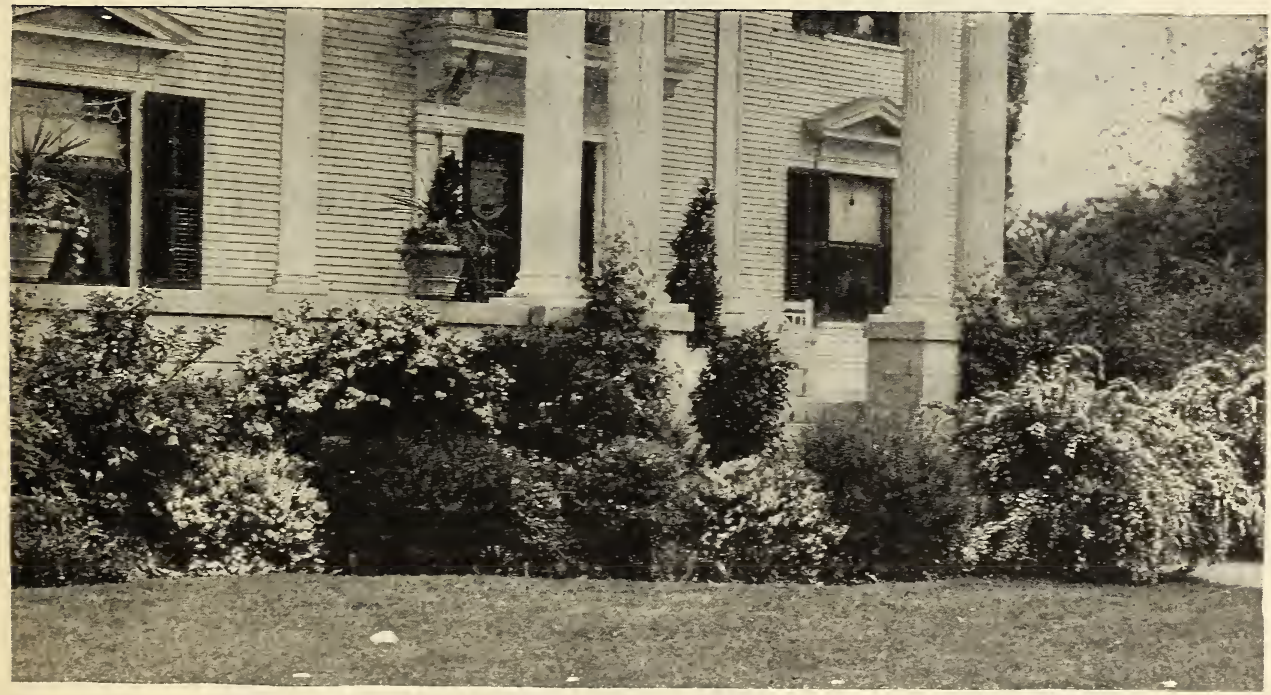

IF I KNEW YOU AND YOU KNEW ME

By W. E. Cooper

If I knew you and you knew me

'Tis seldom we would disagree;

But, never having yet clasped hands,

Both often fail to understand

That each intends to do what's right

And treat each other "honor bright."

How little to complain there'd be

If $I$ knew you and you knew me.

Whene'er we ship you by mistake,

Or in your bill some error make,

From irritation you'd be free

If I knew you and you knew me.

Or when the checks don't come on time,

And customers send nary a line,

We'd wait without anxiety

If I knew you and you knew me.
Or when some goods you "fire back,"

Or make a "kick" on this or that,

We'd take it in good part, you see,

If I knew you and you knew me.

With customers a million strong

Occasionally things go wrong-

Sometimes our fault, sometimes it's theirs-

Forbearance would decrease all cares:

Kind friend, how pleasant things would be

If I knew you and you knew me.

Then let no doubting thoughts abide

Of firm good faith on either side;

Confidence to each other give,

Living ourselves, let others live;

But any time you come this way.

That you will call we hope and pray; Then face to face we each shall see

And I'll know you and you'll know me. 


\section{VITAMITE}

A Scientifically Prepared Special Nitrogenous Bacterial Culture for Promoting all Plant Growth VITAMITE is a special bacteria-differing from all others. It not only benefits legumes but has the same effect on ALL PLANT LIFE.

VITAMITE restores fertility to worn out soilcuts fertilizer bill-gives larger and healthier crops -makes them grow. Pkg., $75 \mathrm{c}$.

VITAMITE-The Bacteria. The best known plant food. Small cartons $75 \mathrm{c}$, large cartons $\$ 1.25$.

QUA SUL-The Germicide. Small bottles $35 \mathrm{c}$, large cans $\$ 1.25$.

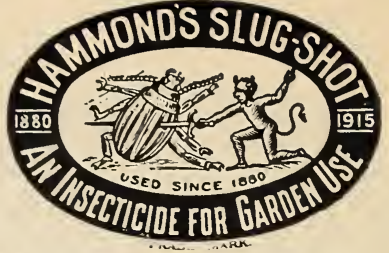

INSECTICIDES AND FUNGICIDES

SLUG SHOT-Used from Ocean to Ocean for 35 Years-Sold by Seed Dealers of America-Saves Currants, Potatoes, Carbage, Melons, Flowers, Trees and Shrubs from Insects. Put up in popular amphlet on Bugs and Blights, etc. $5 \mathrm{lb}$. pkt., $75 \mathrm{c} ; 1 \mathrm{lb}$. pkt. $25 \mathrm{c}$; postpaid, $30 \mathrm{c}$.

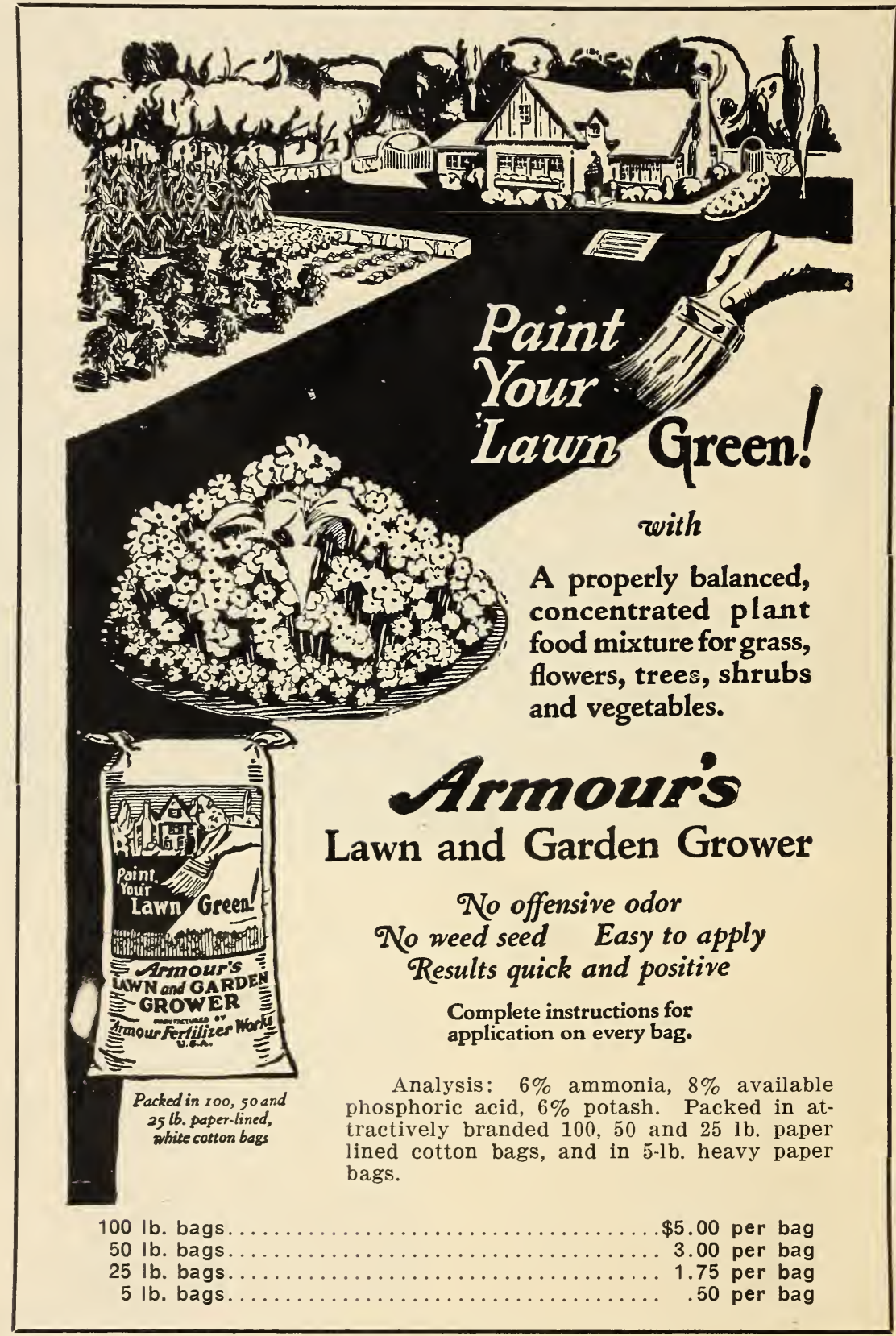




\title{
An InVitation
}

$\mathrm{P}$

LEASE do us the honor by accepting this catalog as a cordial invitation to come in and spend a few moments. We do not want you to

buy unless you find that we have something that you need, and you are sure that our stock is superior and well fitted to satisfactorily fill your needs. By looking over the catalog, it may suggest many items that will make your home and home grounds more beautiful and your orchard more fruitful by planting the best that is to be had both in selection of varieties and quality of stock.

If you do find something that you want, and we are sure that you will, we want the pleasure of supplying that want.

In order that you might get the very best results, we give some general cultural directions that are very important.

LOCATION-We are located half a mile West of New Braunfels and have the best of transportation facilities. The following railways enter New Braunfels: The MI-K-T and I \& G-N.

Yours for better fruits and more beautiful homes,

\section{LOCIE NURSERY AND FLORAL COMPANY.}

\section{A Nuestros Apreciables Clientes Mexicanos:}

Tenemos el gusto de presentarles este nuevo catálogo, esperando que les sea útil en seleccionar sus plantas.

Al hacer sus pedidos, hágannos el favor de escribir su nombre y dirección con toda claridad, para evitar errores.

Pueden escribirnos en castellano, y les aseguramos que sus pedidos serán despachados con todo esmero y puntualidad.

Siempre estamos dispuestos a ayudarles en la selección de árboles, plantas, etc.

We solicit correspondence in English, Spanish or German.

Alle Kunden die Deutsch schreiben koennen Thre Anfragen und Auftraege in Deutscher Sprache einsenden Wir werden alle Auftraege prompt und Gewissenhaft ausfueren und Guarantieren Zufriedenheit.

No. 92

\section{CERTIFICATE OF INSPECTION}

\author{
STATE OF TEXAS
}

Department of Agriculture.

\section{OFFICIAL NURSERY INSPECTION CERTIFICATE}

This is to certify that the nursery and floral stock grown, exhibited or held for sale by Locke Nursery \& Floral Co., at New Braunfels, County of Comal, State of Texas, has been inspected by a duly authorized inspector of this department in accordance with the provisions of the Orchard and Nursery Inspection Laws of the State of Texas, and was found to be apparently free from dangerously injurious insect pests and plant diseases.

A printed copy of this certificate on any shipping tag attached to any shipment of Nursery Stock is authority to any freight or express agent in Texas to accept same for transportation. This certificate is void after September 1, 1928.

Approved:

\section{G. J. SCHOLL,}

GEO. B. TERRELL,

Commissioner of Agriculture

Chief Inspector of Orchards and Nurseries.

Austin, Texas, August 20, 1927 


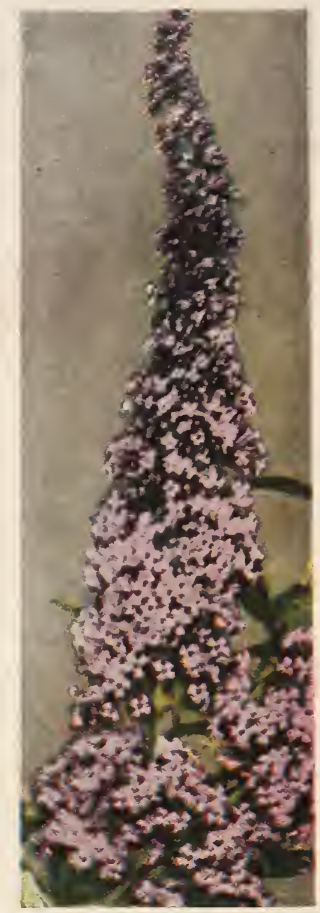

Butterfly Bush

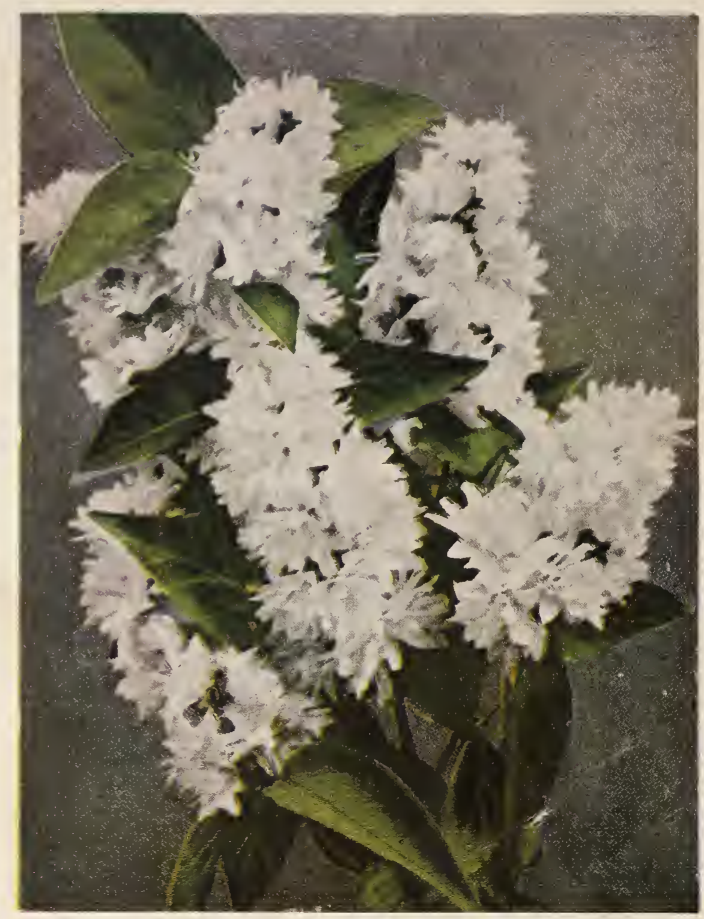

Deutzia

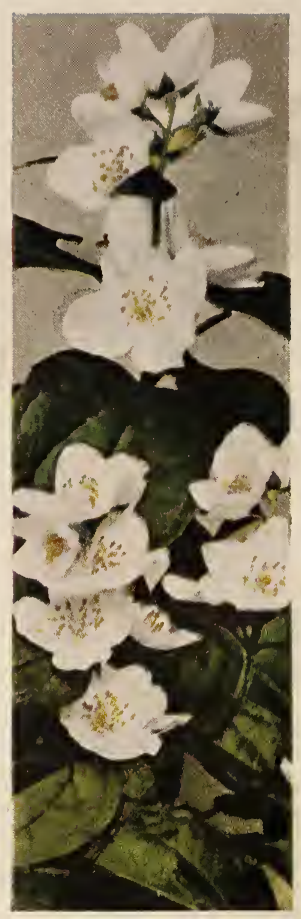

Mock Orange

\section{Shrubs Beautify the Home}

LOCKE NURSERY \& FLORAL CO.

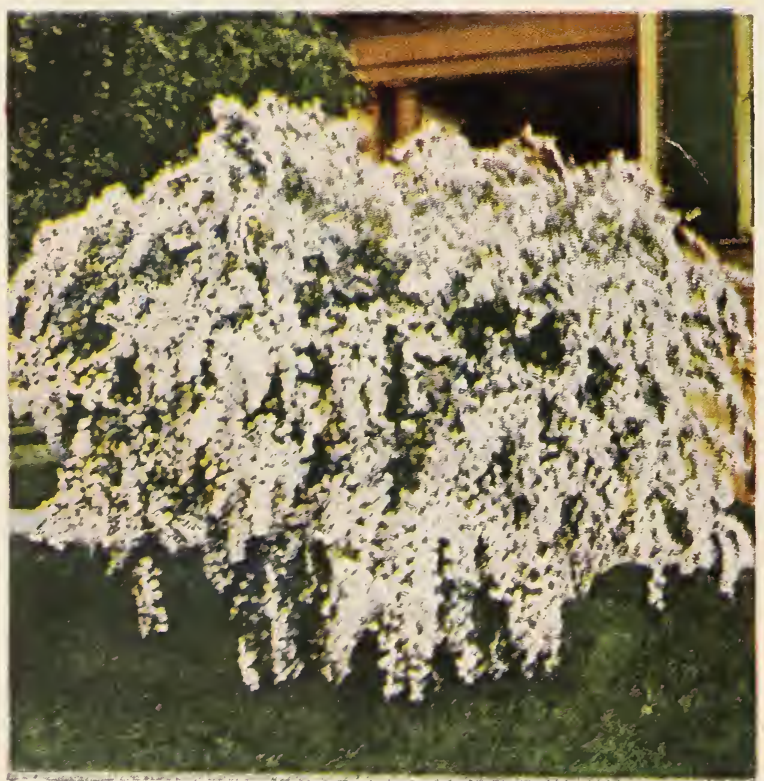

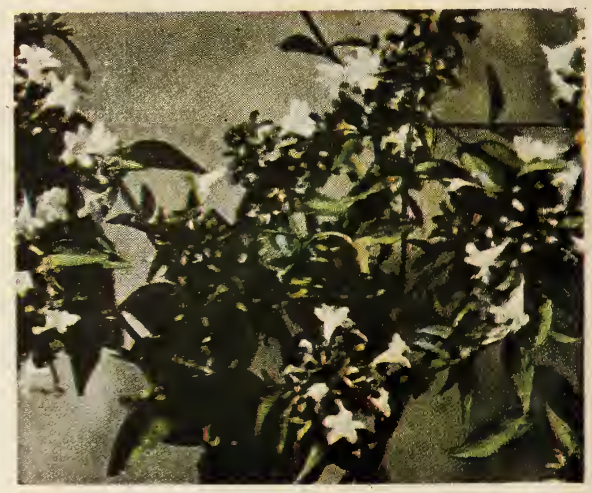

Albelia Grandiflora

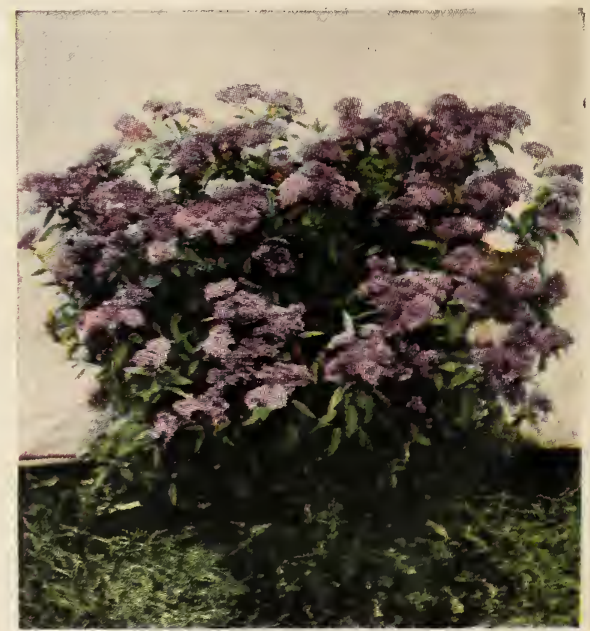

Spirea Anthony Waterer 